\title{
Views of the parents of secondary school students on supporting their children's learning
}

\author{
Gülten Feryal Gündüz ${ }^{* a}$ \\ ${ }^{\text {a } 700 . Y ı l ~ O s m a n g a z i ~ S e c o n d a r y ~ S c h o o l, ~ I ̇ s t a n b u l / T u r k e y ~}$
}

\begin{tabular}{|c|c|}
\hline Article Inf & \\
\hline DOI: 10.31 & 04/ijocis.2019.007 \\
\hline Article His & \\
\hline Received & 11 April 2019 \\
\hline Revised & 07 June 2019 \\
\hline Accepted & 19 June 2019 \\
\hline Online & 30 June 2019 \\
\hline
\end{tabular}

Keywords:

Parental involvement,

Parents of secondary school students,

Secondary school students.

\begin{tabular}{l}
\hline Article Type: \\
Research paper \\
\hline
\end{tabular}

\begin{abstract}
The aim of this study is to identify the views of parents of secondary school students' about their ability to support their children's learning. In this research, concurrent transformative mixed method. A survey was applied to parents; then semi-structured interviews were conducted. Quantitative data were obtained from 300 parents and semi-structured interviews were conducted with 43 parents. According to research findings, the academic support activities carried out by the parents in their children's learning were mostly general academic support activities. Parents provide less support for their children's courses. Parents' support activities to motivate their children to learn are mostly to praise them with nice words. Parents stated that they mostly participated in school meetings in the support activities carried out with the cooperation of persons or institutions that can be effective in the education of their children.
\end{abstract}

\section{Ortaokul öğrenci velilerinin çocuklarının öğrenmelerini destekleme durumlarına ilişkin görüşleri}

\begin{tabular}{|c|c|}
\hline Makale Bi & \\
\hline DOI: 10.31 & 04/ijocis.2019.007 \\
\hline Makale Ge & mişi: \\
\hline Geliş & 11 Nisan 2019 \\
\hline Düzeltme & 07 Haziran 2019 \\
\hline Kabul & 19 Haziran 2019 \\
\hline Çevrimiçi & 30 Haziran 2019 \\
\hline $\begin{array}{l}\text { Anahtar K } \\
\text { Aile katılın } \\
\text { Ortaokul ö } \\
\text { Ortaokul ö }\end{array}$ & $\begin{array}{l}\text { imeler: } \\
\text { renci velileri, } \\
\text { rencileri. }\end{array}$ \\
\hline $\begin{array}{l}\text { Makale Tü } \\
\text { Özgün Ma }\end{array}$ & \\
\hline
\end{tabular}

Öz

Bu araştırmanın amacı ortaokul öğrenci velilerinin çocuklarının
öğrenmelerini destekleyebilme durumlarına ilişkin görüşlerini belirlemektir.
Araştırmada eşzamanlı dönüşümsel karma yöntem kullanılmıştır. Velilere
anket uygulanmış; ardından yarı yapılandırılmış görüşmeler
gerçekleştirilmiştir. Araştırmadaki nicel veriler 300 veliden elde edilmiş; yarı
yapılandırılmış görüşmeler ise 43 veli ile gerçekleştirilmiştir. Araştırma
bulgularına göre velilerin çocuklarının öğrenmelerinde gerçekleştirdikleri
akademik destekleme çalışmaları daha çok genel akademik destekleme
çalışmaları olmaktadır. Çocuklarının derslerine yönelik özel destekleme
çalışmalarını ise daha az yapmaktadırlar. Velilerin çocuklarını öğrenmeye
güdülemek için en fazla gerçekleştirdiklerini ifade ettikleri destekleme
çalışmaları güzel sözlerle onu övmedir. Veliler çocuğunun eğitiminde etkili
olabilecek kişiler ya da kurumların işbirliği ile gerçekleştirdiği destekleme
çalışmalarında ise en fazla okul toplantılarına katıldıklarını belirtmişlerdir.

* Author: gferyal.kucuker@gmail.com 


\section{Introduction}

"Family is the smallest social organization of the society as well as an educational institution. Since family is the place where an individual gains his / her first emotion, behaviour, thought and education." (Kıncal, 1999). In general, parents embrace the role of being the first teachers to teach a lot of knowledge and skills, particularly basic skills such as walking, speaking, and eating until the preschool period (0-6 years). According to Çelenk (2003) cited from Gordon (1993), parents' role of being a teacher in the education process of the children continues, even though this teaching role is significantly transferred to teachers when the child starts school. Therefore, the perception that teachers and schools are primarily responsible for the education of students has been replaced by an understanding that the responsibility of children's education should be shared by the school, family and society. This understanding emphasizes that in order to increase the quality of education in general and student achievement in particular, it is not enough for teachers and schools to work alone, but families should actively involve in this process as well (Lindberg, 2014).

Parental involvement can be defined in many different ways, from the interests, expectations, attitudes, beliefs and aspirations of families towards the education of their children, to their activities at home or at school to support the education of their children (Arens \& Jude, 2017). Different classifications were made by educational scientists regarding the types of parental involvement. Swap (1993; cited by Ünal, Yıldırım \& Çelik, 2000) presented four models of how parents could be involved in their children's education. These models are protective model, school-to-home transmission model, curriculum enrichment model and partnership model (Keith, Kimberly, Sperduto, Santillo \& Killings, 1998). On the other hand, defined family involvement in four dimensions as the expectations of parents from school related to their children, school, parent and child communication, involvement of parents in school activities and involvement of parents in learning activities. Lawson (2003) also stated that there are four different types of involvement. These are creating a child's learning environment at home, paperwork in school such as photocopying, taking part in extracurricular cultural-sportive activities, participating in informative activities about child development, assisting teachers in classroom work, participating in parent-teacher associations (PTAs), taking part in school's decision-making commissions, helping in organization of the school and acting as partners performing the tasks of evaluating and implementing the restructuring strategies and innovations about the school performed by school staff.

The researches indicated that the involvement of the family increased the success of the students (Çelenk, 2003; Hill \& Tyson, 2009; Jeynes, 2007; Kotaman, 2008; Shaw, 2008; Starr, 2011; Şad, 2012), students' negative behaviours and disciplinary problems were decreased (Celep, 2008; Çayak, 2013; Gonzalez-DeHass, Willems \& Holbein, 2005; Sheldon, 2007; Starr, 2011); helped children to develop positive attitudes towards school and teacher (Argon \& Chopper, 2012) and made children more confident, harmonious and happy (Oktay, Gürkan, Zembat \& Unutkan, 2003). It is possible to mention the benefits of family involvement to the child as well as to the teacher and family. The involvement of the families in the education process is effective in achieving the desired goals of the teacher during the education process, performance and success on the student, motivation and easier recognition of the student (Argon \& Chopper, 2012). In addition, as Lindberg and Oğuz (2016) cited from the researches of many educational scientists (Epstein, 1995; Epstein et al., 2002; Epstein \& Sheldon, 2002; Hara \& Burke, 1998), who have significant studies on family involvement, parents could not only have the chance to get to know their children's talents, interests and characteristics better but also could obtain information about the functioning and structure of the school in general.

Rogers, Theule, Ryan, Adams, and Keating (2009) state that there are different perspectives in the researches about family involvement and two important topics emerge. The first one is school-based involvement, which includes communication between parents and teachers and the involvement of parents in institutional events organized by the school. The second one is the out-of-school involvement studies, which investigate the behaviours of parents, such as providing the appropriate learning environment at home, assisting and motivating them with homework, and taking care of the children. It could be said that the studies on family involvement in Turkey are more of the studies that could be handled within the scope of first topic suggested by Rogers et al (2009), namely the studies focusing on school-parent cooperation activities (Akbaşlı \& Kavak, 2008; Çayak, 2013; Çelik, 2005; Özgan \& Aydın, 2010; Porsuk \& Kunt, 2012) which are established and implemented within the framework of school council regulations. The duty of the school-parent associations, established within the framework of the school council regulations, could be defined as "to realize the integration between the school and the family, to provide cooperation between parents and teachers, to support the activities that improve the education and training, to meet the compulsory needs of the students 
who are deprived of financial resources and to contribute financially to the school" (MEB, 2012, item 5/1). Akbaşlı and Kavak (2008) developed a survey based on the tasks in Article 6 of the school council Regulation in their studies aimed at determining the level of fulfilment of the duties of the school councils in secondary schools. The survey consists of five dimensions: "Funding", Improving Teaching", Parent Education", "Improving Physical Conditions" and "Social Cultural Activities". The administrators, teachers and parents in their study believe that the tasks that the school council mostly performs are providing financial support to the school from the parents and the school environment, providing service vehicles for the students, supporting the maintenance and repair of the physical infrastructure of the school, to perform activities ensuring effective communication with the family in order to increase the success of the students and to cooperate with parents in the implementation of the rules to be followed in the school and in the environment of the school. On the other hand, the school group has the highest rate of approve in these views, while the lowest rate of approve belongs to the parents. Based on this result, it could be said that the duties of the school council are mostly financial and besides, it can be said that even the number of the parents who think that these tasks are fulfilled are less than the school administration and teachers. In other studies, where the opinions of administrators , teachers and parents regarding family involvement were obtained (Özgan \& Aydın, 2010; Porsuk \& Kunt, 2012), the most common problems that the administrators encounter were the parents' wish to contact the teachers only when there was a problem in the school, their lack of support to their children, financial problems, lack of knowledge in their children's education, unwillingness to accept the negative aspects of their children, considering parent teacher association conferences as a financial issue, low level of education and teachers' not doing family visitations. While teachers complained that parents came to school only when there was a problem, parents think that they were invited only when a problem arouse or when donations were needed (Özgan \& Aydın, 2010). From the researches, it was seen that the studies conducted for school-family cooperation and parents' involvement in the education of their children are generally limited with financial issues and communication through PTA meetings. Porsuk and Kunt (2012) state that school-family relations in Turkey remain only in the economic level which makes it difficult for parents to participate in the school. Therefore, families cannot discuss with teachers and administrators about the problems they encounter and serious programs cannot be developed for the purpose of school-family cooperation (Porsuk \& Kunt, 2012). In addition to the cooperation issues specified in the school council regulation, it is known that there are many parental behaviours that families can be involved in their children's education affecting the cognitive and affective development and academic success of the children. In line with the definitions and classifications made by educational scientists for family involvement, the involvement of the family in the education process can be defined as "supporting the child's extracurricular (home based) education, participating in school and classroom activities and being closely involved in decision-making processes regarding school programs, school rules and activities (Gündüz, 2018). Therefore, in the researches concerning family involvement, not only the tasks of the school council or common problems encountered in parent-teacher-administration communication, but also the level of parents' support in their children's learning should be investigated. According to Harrison (2003), "education is a totality; parents, society, schools, teachers and peers are all part of this totality and each one of them is an educator. Therefore, success will not be achieved unless parts of the whole support each other (Cited by Özgan \& Aydın, 2010). Therefore, the involvement of parents in the activities carried out within the scope of school council and the kind of activities they do to support their children's education outside the school should be considered as a whole. In the related literature, as can be understood from the above description, parental support and its quality seem to be in need of improvement and extensive studies to guide the extent and quality of parental support is relatively limited especially in terms of extra-curricular activities in Turkey.

On the other hand, the experiences of students vary with the transition to secondary school. In elementary school education, classes are mostly taught by class teachers, while in secondary school there are different branch teachers for almost every lesson. Usually they are in the same class with different students rather than their primary school classmates. (Hill and Tyson, 2009). Additionally, there are some physical, mental, psychological and social changes in adolescence during the age of secondary school students. At this age, students' need for more autonomy in their learning, not wanting to be interfered with their friends, their desire to establish superiority and being admired could affect their communication with their families negatively and cause conflicts (Bayhan \& Işıtan, 2010; Doğan, 2007; Kreider, Caspe, Kennedy, 2010; Doğan, 2007; Kreider, Caspe, Kennedy, 2010; \& Weiss, 2007 act. Thomas, Muls, Backer \& Lombaerts, 2019). These cause the parents of the middle school students to question their support their children's education and how much autonomy they should give to them. Based on these problems and importance, it is considered necessary not only how 
and how much the parents of secondary school students could support their children's extra-curricular education, but also to reveal how much of the studies, which have been recently performed by Ministry of National Education in Turkey focusing on how the parents could support their children's learning, were carried out by parents in practice. The aim of the study is to determine the extent to which the parents of the students could support their children's learning, which support activities they are sufficient in and which should be developed. For this purpose, answers the following questions were searched in the research.

In supporting the learning of the parents' children;

a. What are their views on academic activities they performed?

b. What are their views on motivating activities they performed?

c. What are their views on the activities that they performed with persons who might be influential in their education (school administration, teacher, other parents, friends, etc.)?

The results of the research are thought to be informative for educators about what kind of activities the parents are carrying out to support their children's learning at school and to what extend they are performing the parent behaviours that should be shown. In this context, effective family education programs could be organized by considering the deficiencies of family involvement determined in line with the data obtained. Additionally, the obtained data will also enable parents to identify their own deficiencies in supporting their children's education. Parents who are aware of their shortcomings will also be aware of what kind of education they need in this regard and will be able to contribute more to their children's learning when they improve themselves accordingly. Parents' support of their children's learning with the right methods will positively affect their children's academic achievement and attitudes towards learning.

\section{Method}

\section{The Method of the Research}

In this research, mixed method approach was used. Mixed method is a research design in which qualitative and quantitative data collection and analysis processes are used together for the same purpose in a single study (Creswell, 2003). Different designs have been suggested by researchers on how to use the mixed method (Creswell, 2003; Johnson \& Onwuegbuzie, 2004; Leech \& Onwuegbuzie, 2009; Morse, 2003). When the mixed method designs suggested by the researchers are examined, it is seen that the characteristics considered in the classification of these designs are the purpose of the research, the significance given to the quantitativequalitative methods, which types of data are needed more, and the time and quantity of the quantitative and qualitative methods used during the research. In this study, sequential transformative mixed method design which is included in Creswell's (2003) classification was used. In this design, qualitative and quantitative data collection methods are collected simultaneously as part of the study and the interpretation of the data is made by combining the findings of the two methods in the interpretation stage. Priority is given to the qualitative or quantitative data types, but in some cases equal importance can be given to both data types. This design is useful for providing a wide range of or alternative perspectives, supporting the participants and providing a better understanding of the phenomenon studied (Baki \& Gökçek, 2012; Creswell, 2003). In this context, the opinions of the parents of secondary school students about their support of their children's learning were collected through surveys for quantitative data; for qualitative data, it was collected through semi-structured interviews simultaneously.

\section{Study Group}

Convenience sampling method was used to determine the participants from whom the quantitative data of the research would be collected. This sampling method eliminates the limitations in terms of time, money and labour and provides an easy access and implementation opportunity for sampling (Büyüköztürk, Kılıç-Çakmak, Akgün, Karadeniz \& Demirel, 2017). The reason why the researcher chose this type of sampling in this study was that she was able to reach the participants more easily because she was working in the school that she included in the sampling. The participants of the study consisted of the parents of 5th, 6th, 7th and 8th grade students studying in a secondary school in Istanbul. It consists of 360 parents, 90 of whom are parents of the 
students studying at each grade level. In the study, the participants to be interviewed were selected through simple random sampling method from the sample determined by convenience sampling method. For this purpose, interviews were conducted with 43 parents who were randomly selected from each grade level. Demographic characteristics of the parents in the sample are shown in Table 1.

Table 1.

Demographic Characteristics of the Parents

\begin{tabular}{llrr}
\hline Variant & & $\mathbf{f}$ & \% \\
\hline Parent & Mother & 300 & 100.00 \\
Level of Education & Father & 0 & .00 \\
& Primary School & 137 & 45.70 \\
& Secondary School & 63 & 21.00 \\
& High School & 65 & 21.70 \\
Age Range & University & 4 & 1.30 \\
& Uneducated & 31 & 10.30 \\
& Age 20-30 & 82 & 27.30 \\
Occupation & Age 31-40 & 164 & 54.70 \\
& Age 41-50 & 54 & 18.00 \\
& Housewife & 229 & 76.30 \\
& Self-Employed & 37 & 12.30 \\
& Worker & 22 & 7.30 \\
& Civil Servant & 12 & 4.00 \\
\hline
\end{tabular}

Although the study was not planned to be conducted with mothers, the parents of the students who participated were consisted of mothers. When the educational status of the participants is examined, it is seen that the majority of the participants are primary school graduates. 137 (45.70\%) were primary, 63 (21.00\%) were secondary, $65(21.70 \%)$ were high school and four $(1.30 \%)$ of them were university graduates. 31 $(10.30 \%)$ of the parents stated that they had dropped out of primary school. $82(27.30 \%)$ of the parents were between the ages of $20-30,164(54.70 \%)$ were between the ages of $31-40$ and $54(18.00 \%)$ were between the ages of $41-50.229$ (76.30\%) of the parents were housewives. 37 (12.30\%) of the parents were self-employed, $22(7.30 \%)$ were workers and $12(4.00 \%)$ were civil servants.

\section{Data Collection Tools}

Surveys were used in the collection of quantitative data and semi-structured interview forms were used in collecting qualitative data. The survey used to determine the opinions of the parents about their support on their secondary school children's learning, was prepared by the researcher. While preparing the survey, an item pool was created based on literature (Ministry of National Education Board of Education, 2008; Sheldon \& Epstein, 2007; Walker, Wilkins, Dallaire, Sandler \& Hoover-Dempsey, 2005). The 70-item draft survey was reviewed by six experts consisting of two faculty members working in the field of education programs and teaching; two Turkish Language teachers, one school counsellor and one Turkish Language and Literature professor. These experts evaluated the survey items in terms of scope validity, suitability for the purpose of the research, and clarity of the statements and suggested necessary recommendations. In line with the opinions and suggestions of the experts, eight items were excluded from the survey for reasons such as being ambiguous, measuring the same case and being too long; three items were re-written into two items because of the overlap and length, and the survey was given its final form. The survey was pre-implemented to the parents of 10 students who had not been included in the research. Within the scope of this implementation, there were no problems mentioned by the parents regarding the clarity of the survey. The survey consists of a total of 64 items. 39 items are within the first dimension that is "Activities of Parents' Helping Their Children's Subjects"; 9 items are within the dimension of "Activities of the Parents to Motivate the Children's Learning" and 16 items in the dimension of "Parents' Activities Performed with Other Persons and Institutions for the purpose of supporting the learning of their children". Four-point Likert was used in the survey as "always", "frequently", "sometimes" and "never".

Before finalizing the semi-structured interview form used in the research, the questions prepared were presented to the expert opinion. Three experts, one curriculum development specialist, one Turkish language 
teacher and one school counsellor, were asked to evaluate the interview form in terms of appropriateness of the questions for the purpose of the research and the clarity of the language. In line with the opinions and suggestions of experts, some changes were made in the way of expressing some questions. There were three questions in the interview form. It was highly taken into consideration that these questions were compatible with the dimensions of the survey which was used in the research. In these questions, the parents were asked what academic support activities, motivation activities they carried out to support the learning of their children and the support activities carried out in cooperation with persons or institutions that could be effective in the education of their children. Interviews were conducted in an available classroom of the school on a suitable day and school time determined by each parent and researcher. The interviews were recorded by means of a voice recorder. Interviews with each parent lasted an average of 7-10 minutes. All interviews lasted approximately 370 minutes and were conducted within a week.

\section{Collecting and Analysing the Data}

Class guidance teachers of each class assisted in delivering the surveys to the parents. First of all, the researcher informed the teachers about the scope of the surveys and how to mark them. The class guidance teachers distributed the surveys to the parents at the PTA meeting held in April 2015, made the necessary explanations to the parents and asked the parents to fill out the surveys and deliver to them. 50 of the 360 surveys could not be received; 10 of them were not evaluated due to incomplete or incorrect filling. The data obtained from the remaining 300 surveys were analysed. In the analysis of the quantitative data obtained from the surveys; frequency, percentage and arithmetic mean were used. In the analysis of the qualitative data obtained from the research, descriptive analysis was performed by taking into consideration the dimensions of the survey and the themes created by considering the research questions. Some of the parents' views were directly quoted to support the findings on the themes obtained. The collection and analysis of the quantitative and qualitative data were carried out simultaneously and the findings were presented and interpreted by taking into consideration the questions of the research. For the reliability of the qualitative data, $40 \%$ of the data were analysed by two experts other than the researcher and Miles \& Huberman's (1994) formula (Reliability = Consensus / Consensus + Disagreement) was used in order to determine the reliability between the codings. Individuals who assisted in the analysis of qualitative data of the research were a specialist and doctoral faculty members who are currently working in the Department of Curriculum and Instruction and performed qualitative research studies on different subjects after having taken the qualitative data analysis and scientific research methods courses. Yıldırım and Şimşek (2011) stated that 70\% and above percentage is sufficient. According to Creswell (2013), in order to ensure reliability in a qualitative research, the agreement between the researcher and the expert should be at least $80 \%$. In this research, the reliability (agreement) percentage among the three experts calculated according to the formula of Miles \& Huberman (1994) is 89.00\% and according to the literature, this percentage shows that the qualitative data obtained are reliable. Ethical principles were taken into consideration in the research. In this context, the participants were informed about the research, the participants were convinced to participate voluntarily in the research and the participants were informed that the data to be obtained from the research will be used for scientific purposes only.

\section{Findings}

Taking into consideration the dimensions of the survey and the interview questions, the sub-objectives of the research were presented under three sub-headings; the academic studies carried out by the parents to support their children's learning, motivating activities and collaborative activities with other persons and institutions.

\section{Findings of Academic Studies Carried out by Parents to Support Their Children's Learning}

Table 2 presents the findings of academic activities performed by parents in order to support their children's learning. 
Table 2.

Parents' Views on Academic Activities They Performed

\begin{tabular}{|c|c|c|c|c|c|c|c|c|c|}
\hline \multirow[b]{2}{*}{ Support Activities } & \multicolumn{2}{|c|}{ Always } & \multicolumn{2}{|c|}{ Frequently } & \multicolumn{2}{|c|}{ Sometimes } & \multicolumn{2}{|c|}{ Never } & \multirow{2}{*}{ 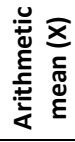 } \\
\hline & f & $\%$ & f & $\%$ & f & $\%$ & $\mathbf{f}$ & $\%$ & \\
\hline Following the studies such as project and performance work. & 149 & 49.70 & 84 & 28.00 & 58 & 19.30 & 9 & 3.00 & 3.24 \\
\hline Examining the daily assignments given by the teacher. & 73 & 24.30 & 79 & 26.30 & 120 & 40.00 & 28 & 9.30 & 2.66 \\
\hline $\begin{array}{l}\text { Encouraging the student to make research by using different learning } \\
\text { resources while doing his / her homework. }\end{array}$ & 173 & 57.70 & 64 & 21.30 & 47 & 15.70 & 16 & 5.30 & 3.31 \\
\hline Using different resources to learn how to support his / her education. & 83 & 27.70 & 66 & 22.00 & 114 & 38.00 & 37 & 12.30 & 2.65 \\
\hline $\begin{array}{l}\text { Obtaining information about the course books and the content of the } \\
\text { curriculum of each course. }\end{array}$ & 83 & 27.70 & 71 & 23.70 & 113 & 37.70 & 33 & 11.00 & 2.68 \\
\hline $\begin{array}{l}\text { Obtaining information about the developmental and psychological } \\
\text { characteristics of his / her age group. }\end{array}$ & 133 & 44.30 & 79 & 26.30 & 65 & 21.70 & 23 & 7.70 & 3.07 \\
\hline $\begin{array}{l}\text { Getting him / her to take into account his / her interests, abilities and } \\
\text { tendencies in his / her learning. }\end{array}$ & 131 & 43.70 & 88 & 29.30 & 64 & 21.30 & 17 & 5.70 & 3.11 \\
\hline Helping him / her to prepare lesson study plan. & 119 & 39.70 & 70 & 23.30 & 75 & 25.00 & 36 & 12.00 & 2.91 \\
\hline $\begin{array}{l}\text { Organizing a learning environment at home that is physically } \\
\text { appropriate to his / her preferences. }\end{array}$ & 166 & 55.30 & 80 & 26.70 & 46 & 15.30 & 8 & 2.70 & 3.35 \\
\hline Sending him / her to school courses and / or studies. & 182 & 60.70 & 53 & 17.70 & 45 & 15.00 & 20 & 6.70 & 3.32 \\
\hline Providing him / her private tutoring. & 72 & 24.00 & 42 & 14.00 & 73 & 24.30 & 113 & 37.70 & 2.24 \\
\hline $\begin{array}{l}\text { Getting him / her to study with his / her successful friends within a } \\
\text { group study. }\end{array}$ & 92 & 30.70 & 58 & 19.30 & 102 & 34.00 & 48 & 16.00 & 2.65 \\
\hline Revising the school subjects together at home. & 45 & 15.00 & 59 & 19.70 & 127 & 42.30 & 69 & 23.00 & 2.27 \\
\hline Getting him / her to do tests about his / her subjects. & 131 & 43.70 & 87 & 29.00 & 71 & 23.70 & 6 & 2.00 & 3.16 \\
\hline $\begin{array}{l}\text { Helping him / her to prepare for the course exams by using different } \\
\text { study techniques }\end{array}$ & 96 & 32.00 & 86 & 28.70 & 89 & 29.70 & 29 & 9.70 & 2.83 \\
\hline $\begin{array}{l}\text { Getting him / her to use the information learned at school in different } \\
\text { and new occasions. }\end{array}$ & 89 & 29.70 & 95 & 31.70 & 89 & 29.70 & 27 & 9.00 & 2.82 \\
\hline Getting him / her to benefit from different learning strategies. & 76 & 25.30 & 98 & 32.70 & 102 & 34.00 & 24 & 8.00 & 2.75 \\
\hline Helping him / her learn according to her own learning style. & 87 & 29.00 & 104 & 34.70 & 86 & 28.70 & 23 & 7.70 & 2.85 \\
\hline $\begin{array}{l}\text { Encouraging him / her to question and to ask questions such as "why", } \\
\text { "how" and "what to do" }\end{array}$ & 107 & 35.70 & 85 & 28.30 & 79 & 26.30 & 29 & 9.70 & 2.91 \\
\hline $\begin{array}{l}\text { Following the scores / results of his / her assignments and exams. } \\
\text { To improve Social Studies - Turkish Lanquage course skills: }\end{array}$ & 207 & 69.00 & 58 & 19.30 & 26 & 8.70 & 9 & 3.00 & 3.54 \\
\hline $\begin{array}{l}\text { Taking him / her to the places, museums, cultural and natural } \\
\text { landmarks that support their learning and are recommended by their } \\
\text { teachers. }\end{array}$ & 85 & 28.30 & 60 & 20.00 & 121 & 40.30 & 34 & 11.30 & 2.65 \\
\hline Doing book reading activities together. & 49 & 16.30 & 58 & 19.30 & 130 & 43.30 & 63 & 21.00 & 2.31 \\
\hline $\begin{array}{l}\text { Doing writing activities on his / her thoughts about people, events and } \\
\text { places that are interesting to him / her in the places he / she visited or } \\
\text { books he / she read. }\end{array}$ & 31 & 10.30 & 58 & 19.30 & 113 & 37.70 & 98 & 32.70 & 2.07 \\
\hline $\begin{array}{l}\text { Going to the cinema and / or theatre together, asking him/ her } \\
\text { questions about the performance, helping him / her understand and } \\
\text { analyse the issue. }\end{array}$ & 70 & 23.30 & 64 & 21.30 & 103 & 34.30 & 63 & 21.00 & 2.47 \\
\hline $\begin{array}{l}\text { Encouraging him / her to speak freely in family and other } \\
\text { environments to express his / her feelings and thoughts. }\end{array}$ & 179 & 59.70 & 63 & 21.00 & 49 & 16.30 & 9 & 3.00 & 3.37 \\
\hline $\begin{array}{l}\text { Getting him / her to observe the changes occurring in nature and } \\
\text { make various inferences about these observations. }\end{array}$ & 95 & 31.70 & 87 & 29.00 & 85 & 28.30 & 33 & 11.00 & 2.81 \\
\hline \multicolumn{10}{|l|}{ To improve Maths skills } \\
\hline $\begin{array}{l}\text { Playing games such as chess, checkers and computer games and so } \\
\text { on. }\end{array}$ & 70 & 23.30 & 57 & 19.00 & 91 & 30.3 & 82 & 27.30 & 2.38 \\
\hline $\begin{array}{l}\text { Solving riddles / puzzles with him / her such as Sudoku and etc. to } \\
\text { make Maths fun. }\end{array}$ & 54 & 18.00 & 45 & 15.00 & 125 & 41.70 & 76 & 25.30 & 2.26 \\
\hline Asking questions about mathematics in daily life events. & 94 & 31.30 & 87 & 29.00 & 02 & 27.30 & 37 & 12.30 & 2.79 \\
\hline $\begin{array}{l}\text { Creating maths problems involving four operations to improve the } \\
\text { mathematics processing skills and to strengthen the value of money } \\
\text { by taking advantage of markets, shopping brochures, etc... }\end{array}$ & 77 & 25.70 & 64 & 21.30 & 108 & 36.00 & 51 & 17.00 & 2.56 \\
\hline $\begin{array}{l}\text { Getting him / her to establish a relationship between various objects } \\
\text { around him / her and geometric shapes and objects. }\end{array}$ & 65 & 21.70 & 58 & 19.30 & 105 & 35.00 & 72 & 24.00 & 2.39 \\
\hline $\begin{array}{l}\text { Drawing his / her attention to the geometry of places such as } \\
\text { museum, historic landmark, work of art etc. seen in newspaper, } \\
\text { magazine etc. }\end{array}$ & 51 & 17.00 & 70 & 23.30 & 107 & 35.70 & 72 & 24.00 & 2.33 \\
\hline $\begin{array}{l}\text { Getting him / her to realize how important it is that measurements } \\
\text { are accurate and used correctly when buying an item for home, } \\
\text { estimating the space of an area, following instructions when installing }\end{array}$ & 85 & 28.30 & 76 & 25.30 & 98 & 32.70 & 41 & 13.70 & 2.68 \\
\hline
\end{tabular}




\begin{tabular}{|c|c|c|c|c|c|c|c|c|c|}
\hline Getting him / her to create tables on topics related to himself / herself & 85 & 28.30 & 78 & 26.00 & 96 & 32.00 & 41 & 13.70 & 2.37 \\
\hline $\begin{array}{l}\text { Getting him / her to examine and interpret the information of the } \\
\text { graphs within his / her interest in written materials. }\end{array}$ & 58 & 19.30 & 69 & 23.00 & 100 & 33.30 & 73 & 24.30 & 2.87 \\
\hline \multicolumn{10}{|l|}{ To improve Science and Technology course skills } \\
\hline Getting him / her to observe the natural events. & 113 & 37.70 & 72 & 24.00 & 79 & 26.30 & 36 & 12.00 & 2.87 \\
\hline $\begin{array}{l}\text { Getting him / her to observe the growth, development and } \\
\text { nourishment of living things. }\end{array}$ & 105 & 35.00 & 70 & 23.30 & 87 & 29.00 & 38 & 12.70 & 2.81 \\
\hline $\begin{array}{l}\text { Drawing his / her attention to the situations in which science is } \\
\text { reflected in technology and examples used in daily life. }\end{array}$ & 57 & 19.00 & 88 & 29.30 & 88 & 29.30 & 67 & 22.30 & 2.45 \\
\hline $\begin{array}{l}\text { Helping him / her develop awareness and responsibility for } \\
\text { environmental issues }\end{array}$ & 156 & 52.00 & 78 & 26.00 & 50 & 16.70 & 16 & 5.30 & 3.25 \\
\hline
\end{tabular}

As can be seen in Table 2, the support activities that parents stated that they do as "always" and "frequently" to help their children's lessons were mostly general academic support activities. The general academic support activities, in which the majority of the parents stated that they do "always" or "frequently" are: Following the studies such as project and performance work, encouraging the student to make research by using different learning resources while doing his / her homework, organizing a learning environment at home that is physically appropriate to his / her preferences, sending him / her to school courses and / or studies, getting him / her to do tests about his / her subjects and following the scores / results of his / her assignments and exams. These support activities were followed by approximately two-thirds of the parents who stated "always" or "frequently" as: obtaining information about the developmental and psychological characteristics of his / her age group, encouraging him / her to question and to ask questions such as "why", "how" and "what to do" and getting him / her to take into account his / her interests, abilities and tendencies in his / her learning. Parents also stated that they sometimes or never performed the activities of using different resources to learn how to support his / her education, providing him / her private tutoring, getting him / her to study with his / her successful friends within a group study and revising the school subjects together at home. As can be seen in Table 1, parents do less specific support activities for their children in Social Studies, Turkish, Science and Technology and Mathematics courses. The most common support activity for verbal courses such as Social Studies and Turkish is encouraging him / her to speak freely in family and other environments to express his / her feelings and thoughts. The activity that most parents stated that they do "sometimes" or "never" is doing writing activities on his / her thoughts about people, events and places that are interesting to him / her in the places he / she visited or books he / she read. In order to improve their mathematical skills, the support activity that was stated by most parents as "always" or "frequently" is asking questions about mathematics in daily life events. The least (sometimes or never) activity in supporting these skills is solving riddles / puzzles with him / her such as Sudoku and etc. to make Maths fun. It was seen that drawing his / her attention to the situations in which science is reflected in technology and examples used in daily life in the development of science and technology lesson skills was the least performed or support activity by the majority of parents. The activity, often referred to as "always" or "often" by the majority of parents in developing their children's skills for this course is helping him / her develop awareness and responsibility for environmental issues. Interviews were also held with parents to determine which academic support activities their children were doing for their children's courses. The opinions obtained from the interviews and their frequency distributions are given in Table 3.

As can be seen in Table 3, 30 of the parents stated that they had helped their children to solve the questions on the subject; 12 of them revised the subjects together; 10 of them stated that they had checked their children's homework. Some of the parents' views on problem solving and revision studies are as follows:

P1: "I'm doing the best I can to help him with all the subjects but especially I get him to doing test exercises on main courses. Sometimes he practices from the textbook that I bought for him and sometimes I benefit from internet. I find tests appropriate for him and with so that he could evaluate himself by keeping time..."

P11: "..I suppose doing test exercises after the revision of the subjects is very important. Therefore, whenever possible, I get him to do test exercises either immediately after or a few days after the revision of the subjects, or write the appropriate questions myself"

P14: “.. for instance, Turkish Language teacher said very nice things to them. He said students would solve 10 problems about the subject and their parents would sign after they check them at the weekend. On Monday students show them to the teacher and every weekend I check whether he did his homework or not". 
Table 3.

Parents' Opinions on Academic Support Activities They Performed*

\begin{tabular}{|c|c|c|c|c|c|c|c|c|}
\hline Theme & Codes & 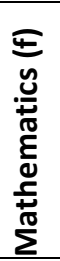 & $\begin{array}{l}\Phi \\
\frac{5}{5} \\
\frac{5}{5} \\
上 \\
F\end{array}$ & 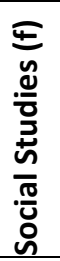 & 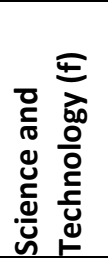 & 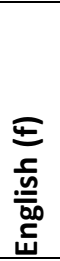 & 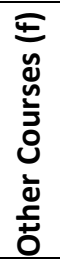 & 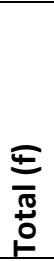 \\
\hline $\begin{array}{l}\text { Academic Support } \\
\text { Activities of }\end{array}$ & $\begin{array}{l}\text { Getting him / her to solve questions } \\
\text { about the subject }\end{array}$ & 22 & 15 & 9 & 16 & 9 & 3 & 30 \\
\hline \multirow[t]{8}{*}{ Parents } & Revising the subject together & 7 & 7 & 7 & 6 & 3 & 3 & 12 \\
\hline & Individual reading & & 11 & & & & & 11 \\
\hline & Checking Homework & 3 & 6 & 3 & 5 & 9 & 2 & 10 \\
\hline & Discussing about school subjects & - & 3 & 4 & - & 1 & - & 6 \\
\hline & Doing research & 2 & 1 & 5 & 2 & 3 & - & 5 \\
\hline & Reading together & - & 4 & - & - & - & - & 4 \\
\hline & Enriching vocabulary & - & 2 & - & - & 4 & - & 4 \\
\hline & Playing educational games & 3 & 2 & 1 & 1 & - & - & 3 \\
\hline
\end{tabular}

* The views of the same parent on the courses are shown separately for each course.

P25: "...our class guidance teacher tells us and the children to do revisions every day. I try to do what he said..."

P34: "Revision is really important. We generally perform a general revision of the subjects of that day before his gets home, I mean before dinner.

P40: "Actually I don't really care about my kid's school subject. But I ask him to finish all the homework and then come and show me. He does what I say

P40: "I check his homework. I do that, but I can't comment whether what he did is right or wrong. For instance, I ask him to show me his English homework. If I see that he did the questions of marked any answer I just say that's okay. But in fact I generally don't know whether the answers are right or wrong..."

It can be said that some of the support activities expressed in the views of the parents varied according to the course taken, in other words support activities were carried out specifically to support specific course(s). 11 parents told that they told their children to read the story / novel books given within the scope of Turkish lesson; 10 parents stated that they had checked their children's homework according to different courses. The most frequently controlled homework by parents was English; the least controlled courses were other than the ones shown in Table 3. Six of the parents stated that they had talked and discussed about the different subjects together chief among of which are Turkish, Social Sciences and English. Five parents stated that they had done research studies for all courses except the ones shown in Table 3. Some of the opinions of the parents who stated that they had read books, chat about school subjects and do research activities are as follows:

P7: I watch some historical show on T.V. I'm deeply interested in history. Some of the themes that I watch on T.V. could be the same themes that my son is learning in Social Studies lesson and we could discuss on these themes. We are really enjoying this.

P8: In Turkish lesson, teacher asks to read books and tell it in front of the class. Teacher also asks questions from the book. When he comes back home I tell him to read the book.

Reading together, enriching vocabulary, playing educational games was the least expressed support activities by parents. Four parents stated that they had been reading books together to improve their skills for Turkish lesson. In total, four parents stated that they had been doing vocabulary exercises for English and / or Turkish courses; three parents stated that they had got their children to play educational games for different courses. Some parents expressed their support activities in their views as follows:

P2: "Well, I mean what I do is general support activities. There are not much activities that I do particularly for each lesson. However, we do reading activities together for Turkish lesson. We read books for half an hour, I mean everybody reads his/her own book." 
P18: We play vocabulary enriching games together. We solve riddles and play scrabble. We sometimes play vocabulary games in which other person derives a new vocabulary item, the first letter of which starts with the last written word's letter.

It could be said that the findings obtained from the interviews also support the survey findings. Findings obtained from both surveys and interviews show that parents are more likely to perform general support activities for all courses in their academic support activities; however, they also show that there is little support for the specific objectives of each course. Particularly, in the interviews conducted with parents, private support activities on Maths and Science courses were stated by very few parents. The majority of the parents stated that they had not done any studies to support their children's learning academically:

P1: "What do you mean by academically? Well I actually don't know much about his lessons. I mostly check whether he did his homework. I can't do any specific activities. I don't have enough knowledge for it, do I?

P12: "Well, you know we do common things. Homework check, helping with the lessons which I know such as Music and Art. I barely help him with the main lessons like Maths and Turkish even if I really want to"

P36: "We can never help. I and his father have a very busy schedule. We don't have much time that's why we can't take care of him.

\section{Findings Regarding the Motivating Activities of Parents to Support Their Children's Learning}

It is important for parents to carry out supportive activities that will motivate them to support their children's learning in order to enable them to learn effectively, with pleasure and awareness of why they are learning. Table 4 shows the findings of parents' views on the activities they performed in order to motivate their children for learning:

Table 4.

Views of the Secondary School Students' Parents of on Motivation Activities

\begin{tabular}{|c|c|c|c|c|c|c|c|c|c|}
\hline \multirow[b]{2}{*}{ Support Activities } & \multicolumn{2}{|c|}{ Always } & \multicolumn{2}{|c|}{ Frequently } & \multicolumn{2}{|c|}{ Sometimes } & \multicolumn{2}{|c|}{ Never } & \multirow{2}{*}{ 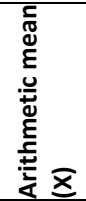 } \\
\hline & $f$ & $\%$ & f & $\%$ & $f$ & $\%$ & $f$ & $\%$ & \\
\hline $\begin{array}{l}\text { Discussing about current events and making him / her to establish a } \\
\text { relationship between these events and what they learned in lessons }\end{array}$ & 122 & 40.70 & 75 & 25.00 & 76 & 25.30 & 27 & 9.00 & 2.97 \\
\hline $\begin{array}{l}\text { Talking about his/her day at school when he/she comes back home } \\
\text { from school }\end{array}$ & 198 & 66.00 & 56 & 18.70 & 38 & 12.70 & 8 & 2.70 & 3.48 \\
\hline $\begin{array}{l}\text { Encouraging him / her to read by reading books and newspapers in } \\
\text { the same room }\end{array}$ & 115 & 38.30 & 74 & 24.70 & 90 & 30.00 & 21 & 7.00 & 2.94 \\
\hline $\begin{array}{l}\text { Encouraging him /her by saying that in case he / she fails, he / she will } \\
\text { succeed if he/ she tries. }\end{array}$ & 224 & 74.70 & 41 & 13.70 & 23 & 7.70 & 12 & 4.00 & 3.59 \\
\hline $\begin{array}{l}\text { Praising him / her with good words when he/ she fulfils his school } \\
\text { responsibilities }\end{array}$ & 214 & 71.30 & 60 & 20.00 & 23 & 7.70 & 3 & 1.00 & 3.62 \\
\hline Rewarding not only his / her achievements, but also his / her efforts & 152 & 50.70 & 65 & 21.70 & 77 & 25.70 & 5 & 2.00 & 3.21 \\
\hline $\begin{array}{l}\text { Taking him / her to an activity he / she likes when he / she fulfils his / } \\
\text { her school responsibilities }\end{array}$ & 105 & 35.00 & 64 & 21.30 & 88 & 29.30 & 43 & 14.30 & 2.77 \\
\hline $\begin{array}{l}\text { Giving him / her the opportunity to do something on his / her own } \\
\text { without any help }\end{array}$ & 187 & 62.30 & 79 & 26.30 & 30 & 10.00 & 4 & 1.30 & 3.50 \\
\hline $\begin{array}{l}\text { Hanging his / her works such as compositions, poetry and painting on } \\
\text { a visible place in the house in order to promote him / her }\end{array}$ & 86 & 28.70 & 78 & 26.00 & 87 & 29.00 & 49 & 16.30 & 2.67 \\
\hline
\end{tabular}

As can be seen in Table 4, in order to motivate their children to learn, the support activities stated by the majority of parents as "always" or "frequently" are: praising him / her with good words when he/ she fulfils his school responsibilities, talking about his / her day at school when he / she comes back home from school and encouraging him /her by saying that in case he / she fails, he / she will succeed if he/ she tries. The support activities stated by the majority of parents as "sometimes" or "never" are: hanging his / her works such as compositions, poetry and painting on a visible place in the house in order to promote him / her and taking him / her to an activity he / she likes when he / she fulfils his / her school responsibilities. During the interviews with the parents, they were also asked what kind of support they were doing in order to motivate their 
children to learn. The opinions obtained from the interviews and their frequency distributions are given in Table 5.

Table 5.

Parents' Opinions on Motivational Support Activities They Performed

\begin{tabular}{llr}
\hline \multicolumn{1}{c}{ Theme } & \multicolumn{1}{c}{ Codes } & $\mathbf{f}$ \\
\hline Motivational & Rewarding his / her achievements & 30 \\
Support Activities & Praising his / her achievements & 25 \\
& Discussing about the benefits of education and training & 20 \\
& Establishing self-confidence on being successful & 13 \\
& Getting him / her to determine his / her own purpose of learning & 7 \\
\hline
\end{tabular}

As can be seen in Table 5, the most frequent motivating activities performed by the parents are praising and rewarding their children's achievements. 30 parents stated that they had rewarded the child when he / she was successful in an exam or an assignment; 25 parents stated that they had given him / her appreciative speeches. Some of the parents' opinions stated in this regard are as follows:

P8: "...If her grades are good and becomes successful, we promise her to take him to a holiday place, seaside or buy whatever she wants."

P10: "I surely reward him when he gets good grades. I do it by buying nice presents or taking him to somewhere in his birthday."

P17: "In case he succeeds something that requires him to work really hard, I buy him something he really wants and I promised before."

P20: "When successful, I reward her by buying her books or taking her to trips."

P27: "Well, it's not always possible for us to buy something to him or do something he wants all the time. But I always praise him whenever she is successful. When successful, I say well done, that's my boy!..."

P36: I think it's important to praise her when she succeeds to do something in order to motivate my child but it should not be exaggerated. My daughter is very emotional so being praised when she succeeds makes her work even harder. I say well done girl! If you keep that way, you will get what you deserve in the future!..."

The second support activities that most frequently mentioned by parents to motivate their children are getting him / her to determine his / her own purpose of learning and establishing self-confidence on being successful. Twenty of the parents stated that they sometimes talk about why learning is important and what the benefits will be for them. Thirteen parents stated that it is very important to make the children believe that they are successful or can succeed if they want. Some parents' views on these support activities are as follows:

P4: "I don't reward my child all the time but when I do, I tell her that studying is her responsibility as a student and talk about the benefits of studying to her. I tell her the importance of learning by saying studying and learning will make her life easier in the future and she will be an intellectual respectable person"

P27: "I talk about the benefits of learning to himself and to the society. I explain the benefits of learning both for himself and for being a good member of a society and give examples about it. For instance..."

P34: In my opinion, in order for my child to be successful, first he should believe that. Therefore, I talk to him not only when he is successful, but also when he is not. I tell him to understand from his mistakes and there is nothing he can't succeed if he pays attention"

P40: “My son never studies to certain lessons. I ask him why and he says he already doesn't understand anything about that lesson. I say first you should believe in yourself and you can do it. You just start studying and see if you can do it or not. I also tell him to ask anything he doesn't understand to his teachers"

Only seven of the parents stated that their children were motivated to learn and that they enabled them to determine their own learning objectives. 
P19: "My son has an aim that is being a pilot. I tell him that if he studies, he could become whichever profession he wants to be and become a pilot in the future. Because in order to become a pilot he should first graduate from a University and it depends on his studies"

P31: My daughter is very ambitious and being successful is very important for her. I ask her why learning is very important to her. I tell her to ask herself and think about what will change in her life if she succeed in learning. For example, she will take scholarship test this year. Being successful in this test is very important for him. She says she is studying to get a high mark from this test and being successful. Actually she is determining on why she studies.

It could be said that taking him / her to an activity he / she likes when he / she fulfils his / her school responsibilities, which is one of the motivation activities stated by the parents during the interviews, does not match the findings obtained from the survey. This support activity was one of the most frequently stated items in the parents' views but in the findings of the survey taking him / her to an activity he / she likes when he / she fulfils his / her school responsibilities was the most frequently stated item by parents as "never". However, the fact that the number of parents who stated as "never" within the total number of parents in the survey was low shows that there is no remarkable discrepancy in the findings obtained from both measurement tools in this context. In general, it could be said that the data obtained from the surveys and interviews about the motivation activities carried out by the parents to support their children's learning correspond each other.

Findings Regarding the Activities of the Parents Which They Performed with the Institutions and Persons that Can Be Effective in Their Education in order to Support Their Children's Learning

Another support activity that parents can use to support their children's learning is the activities they perform with other persons and institutions that can be effective in the education of the child. These persons or institutions could be in a wide range such as friends of their children, school administration, teachers, Ministry of National Education, Directorate of National Education, parents of other students. Table 6 shows the activities of persons with the people who can be effective in the education of their children:

Table 6.

Parents' Views on Activities with Persons and Institutions That Can Be Effective in Their Children's Education

\begin{tabular}{|c|c|c|c|c|c|c|c|c|c|}
\hline \multirow[b]{2}{*}{ Support Activities } & \multicolumn{2}{|c|}{ Always } & \multicolumn{2}{|c|}{ Frequently } & \multicolumn{2}{|c|}{ Sometimes } & \multicolumn{2}{|c|}{ Never } & \multirow{2}{*}{ 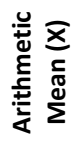 } \\
\hline & f & $\%$ & f & $\%$ & f & $\%$ & f & $\%$ & \\
\hline Attending meetings held in the school & 212 & 70.70 & 54 & 18.00 & 28 & 9.30 & 6 & 2.00 & 3.57 \\
\hline Stating my positive and negative views clearly at school meetings & 155 & 51.70 & 85 & 28.30 & 48 & 16.00 & 12 & 4.00 & 3.28 \\
\hline Trying to meet the teacher when I cannot attend the meeting & 152 & 50.70 & 70 & 23.30 & 64 & 21.30 & 14 & 4.70 & 3.20 \\
\hline Talking to the teacher to get information about my child & 85 & 28.30 & 64 & 21.30 & 110 & 36.70 & 41 & 13.70 & 2.64 \\
\hline Asking others for help if I fail to support my child in a lesson & 80 & 26.70 & 73 & 24.30 & 104 & 34.70 & 43 & 14.30 & 2.63 \\
\hline $\begin{array}{l}\text { Getting information about the developmental characteristics of my } \\
\text { child }\end{array}$ & 120 & 40.00 & 72 & 24.00 & 79 & 26.30 & 29 & 9.70 & 2.94 \\
\hline Contacting to teacher only when my child gets poor grades & 31 & 10.30 & 15 & 5.00 & 64 & 21.30 & 190 & 63.30 & 1.62 \\
\hline $\begin{array}{l}\text { Contacting with the teacher only when I am called to school to talk } \\
\text { about a negative situation about my child }\end{array}$ & 45 & 15.00 & 28 & 9.30 & 73 & 24.30 & 154 & 51.30 & 1.88 \\
\hline Discussing teachers about what to do to support my child's success & 99 & 33.00 & 76 & 25.30 & 92 & 30.70 & 33 & 11.00 & 2.80 \\
\hline Asking the teacher to enlighten me about his educational approach & 111 & 37.00 & 82 & 27.30 & 80 & 26.70 & 27 & 9.00 & 2.92 \\
\hline $\begin{array}{l}\text { Talking both to inform and get information to the teacher about the } \\
\text { strengths and weaknesses, good and bad sides of my child }\end{array}$ & 111 & 37.00 & 80 & 26.70 & 87 & 29.00 & 22 & 7.30 & 2.93 \\
\hline $\begin{array}{l}\text { Obtaining information from the teacher about the syllabus and topics } \\
\text { to be covered }\end{array}$ & 67 & 22.30 & 60 & 20.00 & 108 & 36.00 & 65 & 21.70 & 2.43 \\
\hline $\begin{array}{l}\text { Participating in informative programs, conferences and seminars for } \\
\text { parents }\end{array}$ & 82 & 27.30 & 62 & 20.70 & 104 & 34.70 & 52 & 17.30 & 2.58 \\
\hline $\begin{array}{l}\text { Following different publications published by MEB (Ministry of } \\
\text { National Education) }\end{array}$ & 98 & 32.70 & 72 & 24.00 & 85 & 28.30 & 45 & 15.00 & 2.74 \\
\hline $\begin{array}{l}\text { Participation in family education courses organized by MEB (Ministry } \\
\text { of National Education) }\end{array}$ & 54 & 18.00 & 45 & 15.00 & 84 & 28.00 & 117 & 39.00 & 2.12 \\
\hline $\begin{array}{l}\text { Meeting parents in my child's class and exchange information and } \\
\text { ideas about our children's classes }\end{array}$ & 61 & 20.30 & 65 & 21.70 & 119 & 39.70 & 55 & 18.30 & 2.44 \\
\hline
\end{tabular}

As shown in Table 6, the support activities stated by the majority of the parents as "always" or "frequently" are attending meetings held in the school and stating my positive and negative views clearly at school 
meetings. Support activities that more than half of the parents do "sometimes" or "never" are talking to the teacher to get information about my child, asking others for help if I fail to support my child in a lesson, obtaining information from the teacher about the syllabus and topics to be covered, participating in informative programs, conferences and seminars for parents, participation in family education courses organized by MEB (Ministry of National Education) and meeting parents in my child's class and exchange information and ideas about our children's classes. During the interviews with the parents, they were asked about the kind of activities they carried out together with individuals and institutions that can be effective in education of their children. The opinions obtained from the interviews and their frequency distributions are given in Table 7.

Table 7.

Parents' Views on Activities Performed with Persons and Institutions that Can Be Effective in the Education of Their Children

\begin{tabular}{llr}
\hline Theme & \multicolumn{1}{c}{ Codes } & $\mathbf{f}$ \\
\hline Support Activities & Participating in PTA meetings & 30 \\
Performed with & Going to school when called in case of a problems about the child & 15 \\
Stakeholders & Coming to meeting within the pre-designated parent-teacher meeting hours. & 7 \\
\hline
\end{tabular}

As seen in Table 7, the most frequently expressed support activity by the 25 parents in the interviews with the parents was to participate in the PTA meetings. Here are some of the parents' views on this issue:

P21: "I try to participate in the PTA meetings regularly. Sometimes when I can't participate because of my health issues, I go to school to talk to the teachers in their pre-designated parent-teacher meeting hours so that I can talk face to face."

P32: "I never miss the PTA meetings especially PTA conferences. You have a chance to see all the teachers. You can learn about your child's grades and if you have anything to say in particular, all the teacher are there for you to listen."

There were also parents who stated that they do not attend the parent meetings on purpose. The views of the two parents about the parent meetings are as follows:

P37: "I don't participate in the PTA meetings because the same points are discussed all the times. The point is always about raising donations in PTA meetings. I suppose they call us to school just to say that."

P43: "Actually I don't always participate in the PTA meetings. My son is quite a naughty boy and whenever I go and participate, I always hear complaints. That makes me mad and so I rarely go."

As it can be seen from the above statements, some parents say that they do not go to school when they were called because of a negative situation; 15 parents stated that they go to school in such a situation and meet with the school administration or teacher. Some quotations from the parents' explanations on the issue are as follows:

P8: "My son failed his lass last year. He is both lazy and naughty. School administration warned me that if we don't follow closely, he will fail again. That's why thank god they (school administration - teachers) are taking care of him. So when they call me for a negative situation, I surely go to school."

P13: "Sometimes our children become too naughty and makes the teachers frustrated maybe because of the adolescence period. In such cases, I immediately go to school. When I hear from the teacher what's going on, I can analyze the situation much better..."

Only seven parents stated that they came to meet with the teacher voluntarily at the parents' meeting hours. Some of these parents' opinions are:

P8: “I have always given importance to my children's education. That's why I got all the teachers' parentmeeting hours. I go and meet them in every one and a half month without waiting to be called. I ask if I need to know anything about my child."

P13: "You are not able to talk about your child privately in the PTA meetings. I mean you can't, you don't want to talk in front of all the parents. Sometimes the teacher doesn't have enough time. But our class 
guidance teacher informed us about the parent-teacher meeting times. As nearly no parent is there at these hours, it is more available to talk and I ask him about my child..."

Parents' views on activities performed with persons and institutions that can be effective in the Education of Their Children were evaluated in general. It is often seen that only the teachers and the school administration are the persons with whom the parents cooperate to support their children's learning. In other words, it can be said that they mostly do not communicate with other class parents in order to support their children's learning, they do not create learning environments for their children to work together with their friends outside the school and they do not benefit from the educational opportunities provided by MEB. Another point that draws attention is that parents prefer to have meetings with teachers in the form of PTA meetings and do not conduct one-to-one meetings with their own will.

\section{Discussion, Conclusion and Suggestions}

Since the child's learning process starts with the birth and spends a significant part of his time with his family, it is important that the family support the child's education and learning. In this study, it is aimed to reveal how and how much parents can support their children's learning. Although the concept of parent is considered as the person (s) responsible for the education of the child, it was seen that all participants of the study consisted of mothers, although it was not planned so. Based on this situation, it can be said that mostly mothers have the responsibility of supporting their children's learning. In the studies on family involvement and in the support activities conducted at home in the literature, it is seen that children are mostly studying with their mothers (Edwards \& Gillies, 2011; Jezierski \& Glenda, 2017; Wall, 2013). Another reason why the participants of this study were mothers may be that the majority of mothers are housewives which is in line with the findings of other studies. Göktürk and Dinçkal (2018) stated that parents who are more interested in their children's education are the people are unemployed or not working for long hours. According to the findings of the research, it can be said that parents can perform general academic support activities more than the specific academic support activities for the courses. Considering the studies in the literature (Argon \& Kıyıcı, 2012; Bæck 2010; Hornby \& Blackwell, 2018; Kotaman, 2008; Lareau, 2011;) showing that there is a positive relationship between the educational level of the families and the level of family involvement, it is thought that the educational level might be effective for the parents to perform their general academic support activities relatively more. Additionally, the items related to the academic support activities for the courses in the survey used in the research include support activities that require basic knowledge and skills at the primary school level. Given the fact that the majority of the parents, who have participated in this study were at least primary school graduates. It is likely that the parents do not know how they can perform these detailed support activities rather than the lack of knowledge and skills related to the courses. In his study conducted with parents, Öz (1983) stated that parents wanted to support their children's learning but could not help them because they did not know how to support them (Porsuk \& Kunt, 2012). Gündüz (2018) stated that, one of the topics in the parents' coaching research study that he conducted on social network was that parents had the most expectations from the researcher as a support activity was guidance on how they can support their children on school subjects. Caputo (2007), Lareau (2011) and Tulviste and Kikas (2010) also stated that families have a high desire to know how to perform family involvement in general and how they can help their children with their homework in particular.

One of the important findings of the study is that parents perform more motivating activities to support their children's learning than academic support activities. William, Swift, Williams, and Daal (2017) also stated that in their studies to increase students' self-efficacy with the involvement of parents in school assignments, it is more effective to emphasize the encouraging, modelling and motivation support activities of parents rather than instructional techniques that require mathematics competence. One of the main reasons why parents use motivational support activities more than academic support activities may be that they feel more competent in using motivational activities than academic support activities. It can be said that the strategies used by parents to motivate their children compared to the academic support activities which are used to support their learning are more likely to be encountered in their daily lives. The fact that the educational status of the study participants was mostly primary school graduates or elementary school dropouts may also have been effective in their stating of motivation activities more than others. Bæck (2010) also states that parents with low levels of education feel more inadequate in school-family cooperation studies, especially in supporting their children in academic issues. Similarly, Xu (2016) found that there was no difference in the affective assessments of 
parents in controlling their children's homework according to their educational level; however, it was found that the ability of parents to make cognitive assessment differed according to their educational level. In addition, Gubbins \& Otero (2018) stated that there are many studies showing that people are more willing to participate in activities that they think may be more effective and more beneficial. Hoover-Dempsey et al. (2015), who have important studies on family involvement, associate this situation with self-efficacy that families or parents define as the belief that their knowledge and skills can contribute to their children's education. Another important reason may be that parents think their teachers are responsible for their children's academic learning and they think that their role is to motivate their children to learn and that is what is expected from them.

When we look at the support activities of parents with other people and institutions to support their children's learning, it is seen that these activities are mostly about attending PTA meetings and communicating with the teachers of the child; it is also seen that the number of parents who participated in the activities informative education, conferences, seminars etc. organized by the Ministry of National Education and the school are very few. In the literature, studies regarding international family involvement (Hornby \& Blackwell, 2018; Stanley, Vaterlaus, Tulane \& Beckert 2017; Jezierski \& Wall, 2017), although studies on family education are emphasized in terms of providing academic support to their children such as seminars and conferences, very few studies about this type of educational applications (Badger \& Kunte, 2012) mentioning family involvement studies carried out in Turkey are available. One of the reasons for the lack of involvement of parents in these activities in Turkey may be the way MEB (Ministry of National Education) organizes these activities. These activities, which are organized by the MEB, are generally not applicable to all parents and for some reasons only a part of the parents can benefit from these activities. Parents who benefit from these activities are usually those whose children are at risk for school behaviour or academic achievement, or whose children need special education. In some cases, the parents who will benefit from these activities are randomly selected by the school administration and teachers or by taking into consideration certain criteria determined by the school. For example; in order to strengthen social development and prosperity, MEB organized Family Education Course Programs (0-18 years) with taking into consideration as a priority for family education carried out within the scope of non-formal education activities. The program put into practice includes, Family Education Course Programs for the ages of 0-3, 3-6, 7-11, 12-18, Family Development Course Program for the ages of 3-6, 3-6, Father Support Education Course Program for the age of 7-11 and Illiterate Mother Support Training Course Program (Basic ADP) for the ages of 3- 6 (General Directorate of Lifelong Learning, 2016). These family educational activities are carried out in public education centers within the scope of non-formal education activities organization and MEB and also they are intended for providing services to children of families with low socioeconomic status. Parent academies, which were organized to strengthen the schoolparent communication and cooperation for the parents of the students in the public schools in Istanbul since the 2018-2019 academic year, continue to be unavailable for all parents (Istanbul National Education Directorate, 2019). The subjects that will be explained in the parent academies will be determined by the school administration considering the needs of the parents of the region and the parents who will participate in these parent academies have a certain number of each class in accordance with the physical facilities of the school. It is also possible that parents do not participate in these activities because such activities are not organized in their schools. Akbaşlı and Kavak (2008) stated that they do not have the tools and equipment to enlighten the parents about the education and development of school-parent associations in schools, and also activities for informing parents about informative issues such as the school's program and related regulations are not sufficiently organized. Argon and Kiyici (2012) also mentioned the lack of informative conferences and seminars for all parents in their studies in which they determined teachers' opinions about the involvement of families from primary education institutions and recommends that such activities be actively carried out for all parents by the school administration and teachers after taking the opinions of parents. Parents' meetings were the most important support activities that the parents stated that they carried out with the teacher for family involvement. While the majority of the parents stated that they tried to attend the parent meetings regularly, some of them stated that they did not attend because they thought that the topic discussed in the parent meetings was generally aimed at raising donations for the school and they were disturbed by this situation. In studies conducted especially in Turkey on parent involvement, donations requested from parents, is seen to be in a situation that poses problems for parents, teachers and the school administration. In this context, the findings of the study are consistent with the literature (Albez \& Ada, 2018; Nural, Kaya \& Kaya, 2013; Özgan \& Aygın, 2010; Porsuk \& Kunt, 2012). 
In line with the results of the study, it could be said that parents are not sufficient in general and specific academic support activities about their children's learning. School-parent cooperation also need to be carried out in order to carry out academic activities in which parents feel inadequate to support their children's education, and it is beneficial to organize family education programs for families by schools and MEB. Additionally, it is thought that the inclusion of educational activities in the education programs on how the family can support the school learning of their children, will increase the involvement of the family in their children's education. These educational activities can be directed towards academic supportive activities such as learning strategies, study strategies, the effects of adolescence in this context and the use of technology in education, which will help parents to help their children while they are studying at home or doing their homework. No study investigating the relationship between parent's age and family involvement was found in the literature. As a result of this research, it is considered that the reasons of the relationship between the ages of the parents of the secondary school students and the level of supporting their children's learning should be investigated in more detail. In this research, concurrent mixed method was used. By using the sequential mixed method, detailed interviews can be conducted on the critical findings obtained from the survey, and further investigation of the issues that parents have the most problems in supporting their children's learning can be provided. In the collection of quantitative data in the research, using only the surveys and taking the opinions of parents in the same school could be expressed as the limitations of the research. A similar study should be carried out in consultation with the parents of different schools. On the other hand, it is thought that the use of data collection tools such as scale, which can make further statistical calculations, will be important in terms of examining the relationship between parents' supportive activities and their demographic characteristics. This study conducted with the parents of secondary school students can also be carried out at different levels of education, thus contributing to the analysis of the support activities that families carry out or fail to learn about their children in our education system from a more holistic point of view and to make wider interventions to eliminate the deficiencies of parents. 


\section{TÜRKÇE SÜRÜM}

\section{Giriş}

“Aile, toplumun en küçük sosyal örgütü ve aynı zamanda eğitim kurumudur. Çünkü bireyin ilk duygu, davranış, düşünce ve eğitimini kazandığı yer ailesidir”(Kıncal, 1999). Anne-baba genel olarak çocukların okul öncesi dönemine (0-6 yaş) kadar yürüme, konuşma, yeme gibi temel beceriler başta olmak üzere pek çok bilgi ve becerinin öğretilmesinde ilk öğretmenleri konumundadırlar. Çelenk'in (2003) Gordon'dan (1993) aktardığında göre çocuk okula başladığında bu öğretmenlik rolü önemli ölçüde öğretmenlere geçse de, ebeveynlerin çocuklarının eğitim sürecindeki rolleri devam etmektedir. Bu nedenle öğretmen ve okulların, öğrencilerin eğitimlerinden birincil derecede sorumlu oldukları anlayışı, günümüzde yerini, çocukların eğitimleri ile ilgili sorumluluğunun okul, aile ve toplum tarafından paylaşılması gerektiği yönündeki bir anlayışa bırakmıştır. Bu anlayış, genel olarak eğitimde kaliteyi, özelde ise öğrenci başarısını arttırabilmek için öğretmenlerin ve okulların tek başlarına çalışmalarının yeterli olmadığı, ailelerin de bu sürece aktif olarak katılması gerektiği üzerinde durmaktadır (Lindberg, 2014).

Aile katılımı, ailelerin çocuklarının eğitimine yönelik ilgileri, beklentileri, tutumları, inançları ve isteklerinden onların çocuklarının eğitimine destek için evde ya da okulda gerçekleştirdikleri etkinliklere kadar çok farklı şekillerde tanımlanabilir (Arens \& Jude, 2017). Eğitim bilimciler tarafından aile katılımlarının türlerine ilişkin de farklı sınıflandırmalar yapılmıştır. Swap (1993; Cited by Ünal, Yıldırım \& Çelik, 2000) ailelerin çocuklarının eğitimine nasıl katılabileceklerine ilişkin dört model sunmuştur. Bu modeller; koruyucu model, okuldan eve iletişim modeli, program geliştirme modeli ve işbirliği modelidir. Keith, Keith, Kimberly, Sperduto, Santillo ve Killings (1998) ise, aile katılımını; ailelerin çocuklarıyla ilişkili okuldan beklentileri, okul, veli ve çocuk iletişimi, ailelerin okulda düzenlenen faaliyetlere katılımı ve anne-babaların öğrenme faaliyetlerine katılımı olmak üzere dört boyutta tanımlamışlardır. Lawson (2003) da dört farklı katılım türü olduğunu ifade etmiştir. Bunlar; çocuğun evdeki öğrenme ortamını oluşturma, okuldaki fotokopi gibi kırtasiyecilik işleri, ders dışı ve okul dışı kültürel-sportif etkinlikler ile çocuk gelişimi hakkında bilgilendirici etkinliklere katılma, öğretmenlere sınıf içi çalışmalarında yardımcı olma, veli-öğretmen birliklerine katılma, okulun karar verici komisyonlarında yer alma, okulun düzenlenmesine yardım etme, okul personelinin okul ile ilgili aldığı yeniden yapılanma stratejilerini ve yeniliklerini değerlendirme ve uygulama görevlerini yerine getiren ortaklar olarak görev yapmadır.

Yapılan araştırmalar ailenin eğitime katılımının öğrenci başarısını artırdığını (Çelenk, 2003; Hill \& Tyson, 2009; Jeynes, 2007; Kotaman, 2008; Shaw, 2008; Starr, 2011; Şad, 2012), öğrencilerin olumsuz davranışları ile disiplin sorunlarının azalmasını sağladığını (Celep, 2008; Çayak, 2013;Gonzalez-DeHass, Willems \& Holbein, 2005; Sheldon, 2007; Starr, 2011); çocuğun okula ve öğretmene karşı olumlu tutumlar geliştirmesine yardımcı olduğunu (Argon \& Kıyıcı, 2012) ve çocuğun daha kendine güvenli, uyumlu ve mutlu olmasını sağladığını (Oktay, Gürkan, Zembat \& Unutkan, 2003) göstermektedir. Aile katılımının çocuğa sağladığı faydalar yanında öğretmene ve aileye sağladığı yararlardan da söz etmek mümkündür. Ailelerin eğitim sürecine katılmaları öğretmenin eğitim-öğretim süreci içinde istenilen hedeflere ulaşması, öğrenci üzerindeki performans ve başarısı, motivasyonu ve öğrenciyi daha kolay tanımasında etkili olmaktadır (Argon \& Kıyıcı, 2012). Bunun yanında Lindberg ve Oğuz'un (2016) aile katılımı konusunda önemli çalışmaları bulunan pek çok eğitim bilimcinin (Epstein, 1995; Epstein et. al., 2002; Epstein \& Sheldon, 2002; Hara \& Burke, 1998) araştırmalarından da aktardığı gibi anne-babalar da hem çocuklarının yetenek, ilgi ve özelliklerini daha iyi tanıma şansı elde edebilmekte hem de genel olarak okulun işleyişi ve yapısı ile ilgili bilgi edinebilmektedirler.

Rogers, Theule, Ryan, Adams ve Keating (2009) aile katılımına ilişkin yapılan araştırmalarda farklı bakış açılarının olduğunu ve iki önemli konu başlığının öne çıktığını ifade etmektedirler. Bunlardan ilki, veli ile öğretmenin kurduğu iletişim ve velilerin okul tarafından düzenlenen kurumsal etkinliklere katılımını kapsayan okul temelli katılım; ikincisi ise, velilerin daha çok çocukların akademik gelişimleri ile ilgili olarak evde uygun öğrenme ortamını sağlaması, ev ödevlerinde yardım etmesi ve güdülemesi, çocuğun bakımı gibi davranışlarını araştıran okul dışı katııım çalışmalarıdır. Türkiye'de ise aile katılımına yönelik yapılan araştırmaların daha çok Rogers ve diğerlerinin (2009) ifade ettiği birinci tür araştırmalar kapsamında ele alınabilecek olan Okul-Aile Birliği Yönetmeliği çerçevesinde belirlenen ve yürütülen okul-aile işbirliği etkinliklerine odaklanan çalışmalar (Akbaşlı \& Kavak, 2008; Çayak, 2013; Çelik, 2005; Özgan\& Aydın, 2010; Porsuk \& Kunt, 2012) olduğu söylenebilir. Okul-Aile Birliği yönetmeliği çerçevesinde kurulan okul-aile birliklerinin görevi "okul ile aile arasında bütünleşmeyi gerçekleştirmek, veliler ile öğretmenler arasında işbirliğini sağlamak, eğitim ve öğretimi 
geliştirici faaliyetleri desteklemek, maddi imkânlardan yoksun öğrencilerin zorunlu ihtiyaçlarını karşılamak ve okula maddî katkı sağlamak" olarak tanımlanmaktadır (MEB, 2012). Akbaşlı ve Kavak (2008) ortaöğretim okullarındaki okul aile birliklerinin görevlerini gerçekleştirme düzeylerini belirlemeyi amaçladıkları çalışmalarında Okul-Aile Birliği Yönetmeliği'nin 6.maddesindeki görevleri temele alarak bir anket geliştirmişlerdir. Anket "Kaynak Sağlama", "Öğretimi Geliştirme", "Ana Baba Eğitimi", "Fiziksel Koşulları İyileştirme" ve "Sosyal Kültürel Etkinlikler" olmak üzere beş boyuttan oluşmaktadır. Yaptıkları çalışmada yönetici, öğretmen ve velilerin görüşlerine göre okul-aile birliğinin en fazla yerine getirdiği ifade edilen görevler velilerin ve okul çevresinin okula maddi destekte bulunulmasını sağlama, öğrencilere ulaşım için servis aracı sağlama, okulun fiziki alt yapısının bakım ve onarımlarının yapılmasına destek olma, öğrencilerin başarııının artırmaya yönelik olarak aile ile etkili iletişimini sağlayıcı çalışmalar yapma, okulda ve çevrede uyulması gerekli kuralların uygulanmasında ve izlenmesinde velilerle işbirliği yapma olarak belirtilmişlerdir. Bununla birlikte bu görüşlere en fazla katılan grup okul yönetimi iken en düşük katılma oranı ise velilere aittir. Bu sonuçtan hareketle okul-aile birliğinin belirtilen görevlerinin daha çok maddi konulara yönelik olmasının yanında bu görevlerin dahi yerine getirildiği düşünen velilerin okul yöntemine ve öğretmenlere göre daha az olduğu söylenebilir. Aile katılımına ilişkin yönetici, öğretmen ve veli görüşlerinin alındığı diğer çalışmalarda (Özgan \& Aydın, 2010; Porsuk \& Kunt, 2012) yöneticiler en fazla karşılaşılan sorunları velilerin öğretmenlerle yalnızca okulda bir sorun olduğunda görüşmek istemesi, kendilerine yeterince destek olmamaları, parasal konularda problem çıkarmaları, çocuk eğitimi konusunda bilgili olmamaları, velilerin çocuklarının olumsuz yönlerini kabullenmek istememeleri, velilerin veli toplantılarını ekonomik amaçlı olarak görmeleri, eğitim düzeylerinin düşük olması ve öğretmenlerin aile ziyaretleri yapmamaları olarak ifade etmektedirler. Öğretmenler velilerin okula yalnızca bir sorun olduğunda gelmesinden şikâyetçi iken veliler de kendilerinin okula bir problem ortaya çıktı̆ıında ya da para toplanacağı zaman davet edildiklerini düşünmektedirler (Özgan \& Aydın, 2010). Yapılan araştırmalardan okul-aile işbirliğine ve velilerin çocuklarının eğitimine katıımlarına yönelik yapılan çalışmaların genellikle maddi konular ve veli toplantıları aracılığıyla iletişimin sağlanması ile sınırlı kaldığı görülmektedir. Porsuk ve Kunt (2012) Türkiye'de okul aile ilişkilerinin sadece ekonomik düzeyde kalmasının ailelerin okula katııımlarını güçleştirdiğini belirtmektedirler. Bu yüzden aileler eksik olduğu konular ve karşılaşığı problemler ile ilgili öğretmenlerle ve yöneticilerle görüşememekte ve okul-aile işbirliğinin amacına yönelik ciddi programlar geliştirilememektedir (Porsuk \& Kunt, 2012).

Okul-aile birliği yönetmeliğinde belirtilen işbirliği konuları dışında da ailelerin çocuklarının eğitimlerine katılabilecekleri, onların bilişsel ve duyuşsal gelişimini ve akademik başarılarını etkileyecek çok sayıda veli davranışının olduğu bilinmektedir. Aile katııımına yönelik eğitim bilimciler tarafından yapılan tanımlamalar ve sınıflamalar doğrultusunda ailenin eğitim sürecine katılımı "çocuğunun okul dışı (evdeki) eğitimini destekleme, okul ve sınıf etkinliklerine katılma ve okul programları, okul kuralları ve etkinlikleri ile ilgili karar verme süreçlerinde söz sahibi olma” olarak tanımlanabilir (Gündüz, 2018). Dolayısı ile aile katılımına yönelik yapılan araştırmalarda sadece okul-aile birliğinin görevleri ya da veli-öğretmen-yönetici iletişiminde genel hatları ile karşılaşılan sorunlar değil aynı zamanda velilerin çocuklarının öğrenmelerini ne düzeyde destekleyebildikleri de araştırılmalıdır. Harrison'a (2003) göre de "eğitim bir bütünselliktir; anne-baba, toplum, okul, öğretmen ve akranlar bu bütünün parçalarıdır ve hepsi birer eğitmendir. Dolayısıyla bütünün parçaları birbirini desteklemedikçe başarıya ulaşılamayacaktır" (Cited by Özgan \& Aydın, 2010).Bu nedenle velilerin okul-aile işbirliği kapsamında gerçekleştirilen etkinliklere katııımları ve çocuklarının eğitimini okul dışında desteklemek için ne tür çalışmalar yaptıklarının bir bütün olarak ele alınması gerekmektedir. ilgili alanyazında, yukarıdaki açıklamalardan da anlaşılabileceği gibi, Türkiye'de ailelerin çocuklarının okul dışındaki eğitimlerini desteklemede ne kadar yeterli olduklarını ve hangi konularda eksikliklerinin olduğunu araştıran hem nicelik hem de nitelik açısından kapsamlı bir araştırma bulunmamaktadır. Öte yandan öğrencilerin ortaokula geçişle birlikte deneyimleri de farklılaşmaktadır. Illkokuldaki eğitiminde daha çok sınıf öğretmeni tarafından dersler işlenirken ortaokulda hemen hemen her ders için farklı bir öğretmen olmaktadır. Genellikle ilkokul sınıf arkadaşlarından farklı öğrencilerle aynı sınıfta olmakta; okulu değişmektedir (Hill \& Tyson, 2009). Bununla birlikte ortaokul öğrencilerinin yaşları itibari ile ergenlik döneminde bir takım bedensel, zihinsel, psikolojik ve sosyal değişimler olmaktadır. Bu yaşlarda öğrencilerin öğrenmelerinde daha fazla özerkliğe ihtiyaç duymaları, arkadaşlarına karışılmasını istememeleri, üstünlük kurma ve beğenilme istekleri gibi durumlar aileleri ile olan iletişimlerini de olumsuz yönde etkileyebilmekte, çatışmalara sebep olabilmektedir (Bayhan \& Işıtan, 2010; Doğan, 2007; Kreider, Caspe, Kennedy, \& Weiss, 2007 cited by Thomas, Muls, Backer \& Lombaerts, 2019). Bu durumlar ortaokul öğrenci velilerinin çocuklarının eğitimlerini nasıl desteklemeleri gerektiği ve onlara ne kadar özerklik tanımaları gerektiği konusunda bocalamalarına neden olmaktadır. Bu sorun ve önem durumlarından hareketle hem ortaokul öğrenci velilerinin çocuklarının okul dışındaki öğrenmelerini nasıl ve ne kadar 
destekleyebildikleri hem de MEB tarafından özellikle son yıllarda ailelerin çocuklarının eğitimlerini nasıl destekleyebileceklerine yönelik yapılan çalışmaların uygulamada veliler tarafından ne kadar gerçekleştirilebildiğini ortaya koymanın bir gereklilik olduğu düşünülmüştür. Araştırmanın amacı ortaokul öğrenci velilerinin çocuklarının öğrenmelerini ne kadar destekleyebildiklerini, hangi destekleme çalışmalarında yeterli olduklarını ve hangilerinin geliştirilmesi gerektiğini belirlemektir. Bu genel amaç doğrultusunda araştırmada aşağıdaki sorulara yanıt aranmıştır.

Velilerinin çocuklarının öğrenmelerini desteklemede;

a) Gerçekleştirdikleri akademik etkinliklere yönelik görüşleri nelerdir?

b) Gerçekleştirdikleri güdüleyici etkinliklere yönelik görüşleri nelerdir?

c) Onların eğitimlerinde etkili olabilecek kişiler (okul idaresi, öğretmen, diğer veliler, arkadaşları vs.) ile gerçekleştirdikleri etkinliklere yönelik görüşleri nelerdir?

Araştırmadan elde edilen sonuçların eğitimciler için velilerin çocuklarının okuldaki öğrenmelerini desteklemek için ne tür etkinlikler yaptıkları ve gösterilmesi gereken veli davranışlarını ne kadar gerçekleştirebildikleri konusunda bilgilendirici olacağı düşünülmektedir. Bu bağlamda elde edilen veriler doğrultusunda belirlenen aile katılımı eksiklikleri dikkate alınarak etkili aile eğitim programları düzenlenebilir. Bununla birlikte elde edilen veriler, velilerin de çocuklarının eğitimlerini destekleme konusundaki eksikliklerini belirleyebilmelerini sağlayacaktır. Eksikliklerinin farkında olan veliler bu konuda ne tür bir eğitime ihtiyaçları olduklarının da farkında olacaklar ve bu doğrultuda kendilerini geliştirdiklerinde çocuklarının öğrenmelerine daha fazla katkı sağlayabileceklerdir. Ailelerin çocuklarının öğrenmelerini doğru yöntemlerle desteklemesi ise çocukların akademik başarılarını ve öğrenmeye yönelik tutumlarını olumlu yönde etkileyecektir.

\section{Yöntem}

\section{Araştırmanın Modeli}

Bu araştırmada karma yöntem yaklaşımı kullanılmıştır. Karma yöntem tek bir çalışmada aynı amaç için nitel ve nicel veri toplama ile analiz süreçlerinin birlikte kullanıldığı bir araştırma desenidir (Creswell, 2003). Karma yöntemin nasıl kullanılabileceği konusunda araştırmacılar tarafından farklı karma yöntem tasarımları sunulmuştur (Creswell, 2003; Johnson \& Onwuegbuzie, 2004; Leech \& Onwuegbuzie, 2009; Morse, 2003). Araştırmacıların önerdiği karma yöntem tasarımları incelendiğinde bu tasarımların sınıflandırılmasında dikkate alınan özelliklerin araştırmanın amacı, araştırmada nicel-nitel yöntemlere verilecek olan ağırlık, hangi tür verilere daha fazla ihtiyaç olduğu ile araştırma süresince nicel ve nitel yöntemlerin kullanılma zamanı ve miktarı özellikleri olduğu görülmektedir. Bu araştırmada Creswell (2003)'in sınıflandırmasında yer alan eşzamanlı dönüşümsel karma yöntem tasarımı kullanılmıştır. Bu tasarımda nitel ve nicel veri toplama yöntemleri çalışmanın bir parçası olarak eşzamanlı bir biçimde toplanır ve yorumlama aşamasında iki yöntemin bulguları birleştirilerek verilerin yorumlanmasına gidilir. Öncelik veri türlerinden nitel veya nicel olana verilmekle birlikte bazı durumlarda her iki veri türüne de eşit önem verilebilir. Bu tasarım geniş çaplı veya alternatif bakış açılarına imkân vermesi, araştırmaya katılanları destekleyici olması ve çalışılan olguyu daha iyi anlamayı sağlama bakımından faydalıdır (Baki\& Gökçek, 2012; Creswell, 2003).Bu kapsamda ortaokul öğrenci velilerinin çocuklarının öğrenme durumlarını destekleme durumlarına ilişkin görüşleri nicel veriler için anket; nitel veriler için ise yarı yapılandırılmış görüşmeler yoluyla eş zamanlı olarak toplanmıştır.

\section{Katılımcılar}

Araştırmanın nicel verilerinin toplanacağı katılımcıların belirlenmesinde uygun örnekleme yöntemi kullanılmıştır. Bu örnekleme yöntemi zaman, para ve işgücü açısından var olan sınırlılıkları ortadan kaldırıp, örnekleme kolay ulaşma ve uygulama fırsatı sağlamaktadır (Büyüköztürk, Kılıç-Çakmak, Akgün, Karadeniz \& Demirel, 2017). Bu araştırmada araştırmacının bu örnekleme türünü seçmesinin nedeni örnekleme dâhil ettiği okulda çalışıyor olması nedeni ile katılımcılara daha kolay ulaşabilmesi olmuştur. Araştırmanın katılımcılarını İstanbul ilinde bir ortaokulda öğrenim gören 5, 6., 7. ve 8.sınıf öğrencilerinin velileri oluşturmaktadır. Her bir sınıf düzeyinde öğrenim gören öğrencilerin velilerinden 90'ar kişi olmak üzere toplamda 360 veliden oluşmaktadır. Araştırmada uygun örnekleme yolu ile belirlenen örneklem içerisinden basit tesadüfi örnekleme 
yöntemi ile görüşmelerin yapılacağı katılımcılar seçilmiştir. Bunun için her bir sınıf düzeyinden rastlantısal olarak belirlenen 43 öğrenci velisi ile görüşmeler gerçekleştirilmiştir. Örneklemde yer alan velilerin demografik özellikleri Tablo 1'de görülmektedir.

Tablo 1.

Velilerin Demografik Özellikleri

\begin{tabular}{llrr}
\hline Değişken & & $\mathbf{f}$ & \% \\
\hline Veli & Anne & 300 & 100.00 \\
Eğitim Durumu & Baba & 0 & .00 \\
& İlkokul & 137 & 45.70 \\
& Ortaokul & 63 & 21.00 \\
& Lise & 65 & 21.70 \\
& Üniversite & 4 & 1.30 \\
Yaş Aralığı & Okumamış & 31 & 10.30 \\
& 20-30 yaş & 82 & 27.30 \\
& 31-40 yaş & 164 & 54.70 \\
Meslek & 41-50 yaş & 54 & 18.00 \\
& Ev hanımı & 229 & 76.30 \\
& Serbest meslek & 37 & 12.30 \\
& İş̧i & 22 & 7.30 \\
& Memur & 12 & 4.00 \\
\hline
\end{tabular}

$\mathrm{Bu}$ araştırmaya katılan velilerin tümünün annelerden oluştuğu görülmüştür. Araştırmanın annelerle gerçekleştirilmesi planlanan bir durum olmamakla birlikte katılımcı olan öğrenci velileri annelerden oluşmuştur. Katılımcıların eğitim durumları incelendiğinde çoğunluğunun ilkokul mezunu olduğu görülmektedir. 137'si (\% 45.70) ilkokul, 63'ü (\%21.00) ortaokul, 65’i (\% 21.70) lise ve dördü de (\% 1.30) üniversite mezunudur. Velilerin $31^{\prime} \mathrm{i}$ (\% 10.30) ise ilkokul terk olduklarını belirtmişlerdir. Velilerin yaşları 82'sinin (\%27.30) 20-30 yaş, 164'ünün (\%54.70) 31-40 ve 54'ünün (\% 18.00) 41-50 yaş arasındadır. Velilerin 229’u (\% 76.30) ev hanımıdır. Velilerin 37 'si (\% 12.30) serbest meslek sahibi, 22 'si (\% 7.30) işçi ve 12 'si (\% 4.00) ise memurdur.

\section{Veri Toplama Araçları}

Araştırmanın nicel verilerinin toplanmasında anket; nitel verilerinin toplanmasında ise yarı yapılandırılmış görüşme formu kullanılmıştır. Ortaokul velilerinin çocuklarının öğrenmelerini destekleme durumlarına ilişkin görüşlerini belirleme anketi araştırmacı tarafından hazırlanmıştır. Anket hazırlanırken öncelikle alanyazına dayalı olarak madde havuzu oluşturulmuştur (Milli Eğitim Bakanlığı Talim ve Terbiye Kurulu Başkanlığı, 2008; Sheldon \& Epstein, 2007; Walker, Wilkins, Dallaire, Sandler \& Hoover-Dempsey, 2005). Oluşturulan 70 maddelik taslak anket ikisi eğitim programları ve öğretim alanında görev yapan öğretim üyesi; ikisi Türkçe öğretmeni, biri Okul Psikolojik Danışmanı ve biri Türk dili ve edebiyatı alanında görev yapan öğretim üyesi olan toplam altı uzmanın görüşüne sunulmuştur. Bu uzmanlar anket maddelerini kapsam geçerliği, araştırmanın amacına uygunluğu ile ifadelerin açık ve anlaşılırlığı açılarından değerlendirmişler ve önerilerde bulunmuşlardır. Uzmanların görüş ve önerileri doğrultusunda sekiz madde anlaşılır olmama, aynı şeyi ölçme ve çok uzun olma gibi gerekçelerle anketten çıkarılmış; üç madde de binişiklik olması ve uzun olması nedeniyle iki madde halinde yazılmış ve ankete son hali verilmiştir. Anketin, araştırma kapsamına alınmayan 10 ortaokul öğrenci velisine ön uygulaması yapılmıştır. Bu uygulama kapsamında velilerden anketin anlaşılırlığına ilişkin herhangi bir sorun belirtilmemiştir. Anketin birinci boyutu olan "Velinin Çocuğunun Derslerine Yardımcı Olma Etkinlikleri" boyutunda 39 madde; "Velinin Çocuğunun Öğrenmelerini Güdüleyici Etkinlikleri" boyutunda 9 madde ve son boyut olan "Velinin Çocuğunun Öğrenmesini Desteklemek Amacıyla Diğer Kişiler ve Kurumlar ile Gerçekleştirilen Etkinlikler" boyutunda ise 16 madde olmak üzere üç boyuttan ve toplam 64 maddeden oluşmaktadır. Ankette "her zaman”, “çoğu zaman”, "bazen”, “hiçbir zaman” olmak üzere dörtlü likert kullanılmıştır.

Araştırmada kullanılan yarı yapılandırılmış görüşme formuna son şekli verilmeden önce hazırlanmış olan sorular uzman görüşüne sunulmuştur. Biri program geliştirme uzmanı; biri Türkçe öğretmeni ve biri de Okul 
psikolojik danışmanı olmak üzere üç uzmandan görüşme formunu soruların araştırmanın amacına uygunluğuna ve dil açısından anlaşılırlığına yönelik değerlendirmeleri istemiştir. Uzmanların görüş ve önerileri doğrultusunda bazı soruların ifade ediliş şekillerinde ufak değişiklikler yapılmıştır. Görüşme formunda üç soru yer almaktadır. Bu soruların araştırmada kullanılan ankette yer alan boyutlar ile uyumlu olmasına dikkat edilmiştir. Bu sorularda velilere çocuklarının öğrenmelerini desteklemede gerçekleştirdikleri akademik destekleme çalışmalarının, güdüleme etkinliklerinin ve çocuklarının eğitiminde etkili olabilecek kişi ya da kurumların işbirliği ile gerçekleştirdiği destekleme çalışmalarının neler olduğu sorulmuştur. Görüşmeler her bir veli ile araştırmacının belirlediği uygun bir gün ve okul saatinde okulun boş bir sınıfında gerçekleştirilmiştir. Gerçekleştirilen görüşmeler ses kayıt cihazı kullanılarak kaydedilmiştir. Her bir veli ile görüşmeler ortalama 7-10 dakika sürmüştür. Tüm görüşmeler yaklaşık 370 dakika sürmüş ve bir hafta içerisinde gerçekleştirilmiştir.

\section{Verilerin Toplanması ve Analizi}

Anketlerin velilere ulaştırılmasında her bir sınıfın şube rehber öğretmeni yardımcı olmuştur. Öncelikle araştırmacı öğretmenleri anketlerin kapsamı ve nasıl işaretleme yapılacağı konusunda bilgilendirmiştir. Şube rehber öğretmenleri anketleri velilere 2015 yılı Nisan ayında yapılan genel veli toplantısında dağıtmış, velilere ankete ilişkin gerekli açıklamaları yapmış ve velilerden anketleri doldurarak kendilerine ulaştırmalarını istemişlerdir. 360 anketten 50 tanesi geri dönmemiş; 10 tanesi ise eksik ya da yanlış doldurulduğu için değerlendirmeye alınmamıştır. Geriye kalan 300 anketten elde edilen veriler analiz edilmiştir. Anketlerden elde edilen nicel verilerin analizinde frekans, yüzde ve aritmetik ortalama kullanılmıştır. Araştırmadan elde edilen nitel verilerin analizinde ise ankette yer alan boyutlar ve araştırma soruları dikkate alınarak oluşturulmuş olan temalar dikkate alınarak betimsel analiz gerçekleştirilmiştir. Elde edilen temalara ilişkin bulguların desteklenmesinde velilerin görüşlerinden bazıları doğrudan alıntı olarak verilmiştir. Nicel ve nitel verilerin toplanması ve analizi eş zamanlı olarak gerçekleştirilmiş ve elde edilen bulgular araştırmanın soruları dikkate alınarak birlikte sunulmuş ve yorumlanmıştır. Nitel verilerin güvenirliği için verilerin \% 40.00'ının araştırmacı dışında iki uzman tarafından analiz edilmesi sağlanmış ve kodlamaları arasındaki güvenirliğin belirlenmesinde Miles \& Huberman'ın (1994) formülü (Güvenirlik= Görüş birliği/ Görüş birliği + Görüş ayrılığı) kullanılmıştır. Araştırmanın nitel verilerin analizinde yardımcı olan uzmanla bir üniversitenin Eğitim Programları ve Öğretim anabilim dalında görev yapmakta olan ve bilimsel araştırma yöntemleri ile nitel veri analizi derslerini alarak farklı konularda nitel araştırma çalışmaları yapmış doktor öğretim üyeleridir. Yıldırım ve Şimşek (2011) bu yüzdenin \%70.00 ve üzeri olmasının yeterli olduğunu belirtmektedir. Creswell'e (2013) göre nitel bir araştırmada güvenirliğin sağlanması için araştırmacı ile uzman arasındaki uyumun en az \% 80.00 olması gerekmektedir. Bu araştırmada Miles ve Huberman'ın (1994) formülüne göre hesaplanan üç uzman arasındaki güvenirlik (uyuşum) yüzdesi \% 89.00’dur ve alanyazına göre bu yüzde elde edilen nitel verilerin güvenilir olduğunu göstermektedir. Araştırmada etik ilkeler dikkate alınmıştır. Bu bağlamda katılımcılar araştırma hakkında bilgilendirilmiş, katılımcıların araştırmaya gönüllü olarak katılması sağlanmış ve katılımcılara araştırmadan elde edilecek verilerin sadece bilimsel amaçlı kullanılacağı belirtilmiştir.

\section{Bulgular}

Araştırmanın alt amaçları, ankette yer alan boyutlar ve görüşme soruları dikkate alınarak velilerin çocuklarının öğrenmelerini desteklemeye yönelik gerçekleştirdikleri çalışmalar akademik etkinlikler, güdüleyici etkinlikler ile diğer kişiler ve kurumlar ile işbirliğine dayalı gerçekleştirdikleri etkinlikler olmak üzere üç alt başlık altında sunulmuştur.

\section{Velilerin Çocuklarının Öğrenmelerini Desteklemek İçin Gerçekleştirdikleri Akademik Etkinliklere ilişkin Elde Edilen Bulgular}

Tablo 2'de velilerin çocuklarının öğrenmelerini desteklemek için gerçekleştirdikleri akademik etkinliklere ilişkin elde edilen bulgular sunulmuştur. 
Tablo 2.

Velilerin Gerçekleştirdikleri Akademik Etkinliklere Yönelik Görüşleri

\begin{tabular}{|c|c|c|c|c|c|c|c|c|c|}
\hline \multirow[b]{2}{*}{ Destekleme Çalışmaları } & \multicolumn{2}{|c|}{ Her zaman } & \multicolumn{2}{|c|}{$\begin{array}{l}\text { Çoğu } \\
\text { zaman }\end{array}$} & \multicolumn{2}{|c|}{ Bazen } & \multicolumn{2}{|c|}{$\begin{array}{l}\text { Hiçbir } \\
\text { zaman }\end{array}$} & \multirow{2}{*}{ 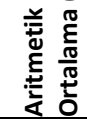 } \\
\hline & $\mathbf{f}$ & $\%$ & $f$ & $\%$ & $f$ & $\%$ & $\mathbf{f}$ & $\%$ & \\
\hline Proje ve performans ödevi gibi çalışmalarını takip etme & 149 & 49.70 & 84 & 28.00 & 58 & 19.30 & 9 & 3.00 & 3.24 \\
\hline Öğretmen tarafından verilen günlük ödevlerini inceleme & 73 & 24.30 & 79 & 26.30 & 120 & 40.00 & 28 & 9.30 & 2.66 \\
\hline $\begin{array}{l}\text { Ödevlerini yaparken farklı öğrenme kaynaklarından faydalanarak onu } \\
\text { araştırma yapmaya teşvik etme }\end{array}$ & 173 & 57.70 & 64 & 21.30 & 47 & 15.70 & 16 & 5.30 & 3.31 \\
\hline $\begin{array}{l}\text { Eğitimini nasıl destekleyebileceğimle ilgili bilgi edinmek için farklı } \\
\text { kaynaklardan yararlanma }\end{array}$ & 83 & 27.70 & 66 & 22.00 & 114 & 38.00 & 37 & 12.30 & 2.65 \\
\hline $\begin{array}{l}\text { Ders kitapları ve her dersin eğitim programının içeriği hakkında bilgi } \\
\text { edinme }\end{array}$ & 83 & 27.70 & 71 & 23.70 & 113 & 37.70 & 33 & 11.00 & 2.68 \\
\hline $\begin{array}{l}\text { Çocuğumun içinde bulunduğu yaş grubunun gelişimsel ve psikolojik } \\
\text { özellikleri hakkında bilgi edinme }\end{array}$ & 133 & 44.30 & 79 & 26.30 & 65 & 21.70 & 23 & 7.70 & 3.07 \\
\hline $\begin{array}{l}\text { Çocuğumun öğrenmelerinde ilgi, yetenek ve eğilimlerini dikkate } \\
\text { almasını sağlama }\end{array}$ & 131 & 43.70 & 88 & 29.30 & 64 & 21.30 & 17 & 5.70 & 3.11 \\
\hline Ders çalışma planı hazırlamasına yardımcı olma & 119 & 39.70 & 70 & 23.30 & 75 & 25.00 & 36 & 12.00 & 2.91 \\
\hline $\begin{array}{l}\text { Evde fiziksel olarak çocuğumun tercihlerine uygun bir öğrenme ortamı } \\
\text { düzenleme }\end{array}$ & 166 & 55.30 & 80 & 26.70 & 46 & 15.30 & 8 & 2.70 & 3.35 \\
\hline Okulda açılan kurslara ve/veya etütlere gönderme & 182 & 60.70 & 53 & 17.70 & 45 & 15.00 & 20 & 6.70 & 3.32 \\
\hline Özel ders almasını sağlama & 72 & 24.00 & 42 & 14.00 & 73 & 24.30 & 113 & 37.70 & 2.24 \\
\hline Başarılı arkadaşları ile grup oluşturarak birlikte çalışmasını sağlama & 92 & 30.70 & 58 & 19.30 & 102 & 34.00 & 48 & 16.00 & 2.65 \\
\hline Derslerin evde birlikte tekrarını yapma & 45 & 15.00 & 59 & 19.70 & 127 & 42.30 & 69 & 23.00 & 2.27 \\
\hline Dersleri ile ilgili test çözmesini sağlama & 131 & 43.70 & 87 & 29.00 & 71 & 23.70 & 6 & 2.00 & 3.16 \\
\hline $\begin{array}{l}\text { Farklı çalışma tekniklerini kullanarak ders sınavlarına hazırlanmasına } \\
\text { yardımcı olma }\end{array}$ & 96 & 32.00 & 86 & 28.70 & 89 & 29.70 & 29 & 9.70 & 2.83 \\
\hline $\begin{array}{l}\text { Okulda derslerinde öğrendiği bilgileri okul dışında yeni durumlarda } \\
\text { kullanmasını sağlama }\end{array}$ & 89 & 29.70 & 95 & 31.70 & 89 & 29.70 & 27 & 9.00 & 2.82 \\
\hline Farklı öğrenme stratejilerinden yararlanmasını sağlama & 76 & 25.30 & 98 & 32.70 & 102 & 34.00 & 24 & 8.00 & 2.75 \\
\hline $\begin{array}{l}\text { Öğrenmelerini kendi öğrenme stiline göre gerçekleştirmesine yardımcı } \\
\text { olma }\end{array}$ & 87 & 29.00 & 104 & 34.70 & 86 & 28.70 & 23 & 7.70 & 2.85 \\
\hline $\begin{array}{l}\text { "Neden". "nasıl" ve "ne yapmalı" gibi sorular sormaya ve sorgulama } \\
\text { yapmaya teşvik etme }\end{array}$ & 107 & 35.70 & 85 & 28.30 & 79 & 26.30 & 29 & 9.70 & 2.91 \\
\hline Yaptığı ödevlerden ve sınavlardan aldığı sonuçları takip etme & 207 & 69.00 & 58 & 19.30 & 26 & 8.70 & 9 & 3.00 & 3.54 \\
\hline Sosyal bilimler-Türkçe dersi becerilerini geliştirmek için; & & & & & & & & & \\
\hline $\begin{array}{l}\text { Öğrenmelerini destekleyici ve öğretmenlerinin önerdiği mekânları, } \\
\text { müzeleri, kültür ve tabiat varlıklarını gezmeye götürme }\end{array}$ & 85 & 28.30 & 60 & 20.00 & 121 & 40.30 & 34 & 11.30 & 2.65 \\
\hline Birlikte kitap okuma etkinlikleri yapma & 49 & 16.30 & 58 & 19.30 & 130 & 43.30 & 63 & 21.00 & 2.31 \\
\hline $\begin{array}{l}\text { Gezdiğimiz yerlere ya da okuduğu kitaplara yönelik kendisine ilginç } \\
\text { gelen kişi, olay ve yerler hakkındaki düşüncelerini yazma çalışmaları } \\
\text { yaptırma }\end{array}$ & 31 & 10.30 & 58 & 19.30 & 113 & 37.70 & 98 & 32.70 & 2.07 \\
\hline $\begin{array}{l}\text { Birlikte sinemaya ve/veya tiyatroya giderek izlenenler doğrultusunda } \\
\text { ona sorular sorma. Onun konuyu anlamasına ve çözümlemesine } \\
\text { yardımcı olma }\end{array}$ & 70 & 23.30 & 64 & 21.30 & 103 & 34.30 & 63 & 21.00 & 2.47 \\
\hline $\begin{array}{l}\text { Aile ortamında ve diğer ortamlarda konuşmaya cesaretlendirerek } \\
\text { duygu ve düşüncelerini rahatça ifade etmesini sağlama }\end{array}$ & 179 & 59.70 & 63 & 21.00 & 49 & 16.30 & 9 & 3.00 & 3.37 \\
\hline $\begin{array}{l}\text { Doğada meydana gelen değişimleri gözlemlemesini ve bu gözlemlere } \\
\text { iliş̧in çeşitli çıkarımlarda bulunmasını sağlama }\end{array}$ & 95 & 31.70 & 87 & 29.00 & 85 & 28.30 & 33 & 11.00 & 2.81 \\
\hline Matematik becerilerini geliştirmek için; & & & & & & & & & \\
\hline Satranç, dama, bilgisayar oyunları vb. oyunlar oynama & 70 & 23.30 & 57 & 19.00 & 91 & 30.30 & 82 & 27.30 & 2.38 \\
\hline $\begin{array}{l}\text { Matematiği eğlenceli hale getirmek için çocuğumla sudoku vb. } \\
\text { bilmeceleri çözme }\end{array}$ & 54 & 18.00 & 45 & 15.00 & 125 & 41.70 & 76 & 25.30 & 2.26 \\
\hline Günlük yaşantımızdaki olaylarda matematiğe ilişkin sorular sorma & 94 & 31.30 & 87 & 29.00 & 82 & 27.30 & 37 & 12.30 & 2.79 \\
\hline $\begin{array}{l}\text { Matematik işlem becerisini geliştirmek için para kullanım alanlarını ve } \\
\text { değerlerini pekiştirmek amacıyla marketlerden, alışveriş } \\
\text { broşürlerinden vb. yararlanarak dört işlem içeren problemler } \\
\text { oluşturma }\end{array}$ & 77 & 25.70 & 64 & 21.30 & 108 & 36.00 & 51 & 17.00 & 2.56 \\
\hline $\begin{array}{l}\text { Çevresinde gördüğü çeşitli nesneler ile geometride öğrendiği çeşitli } \\
\text { şekil ve cisimler arasında ilişki kurmasını sağlama }\end{array}$ & 65 & 21.70 & 58 & 19.30 & 105 & 35.00 & 72 & 24.00 & 2.39 \\
\hline $\begin{array}{l}\text { Gazete, dergi vb. yayınlarda; müze, tarihi eserler, sanat eserleri vb. } \\
\text { yerlerde bulunan geometriyle ilgili kısımlara dikkatini çekme }\end{array}$ & 51 & 17.00 & 70 & 23.30 & 107 & 35.70 & 72 & 24.00 & 2.33 \\
\hline $\begin{array}{l}\text { Eve bir eşya alırken, bir alanı tahmin ederken, bir eşyayı monte etme } \\
\text { talimatlarını izlerken ölçülerin doğru olmasının ve doğru } \\
\text { kullanılmasının ne kadar önemli olduğunu fark ettirme }\end{array}$ & 85 & 28.30 & 76 & 25.30 & 98 & 32.70 & 41 & 13.70 & 2.68 \\
\hline Kendi ile ilgili konularda tablolar oluşturmasını sağlama & 85 & 28.30 & 78 & 26.00 & 96 & 32.00 & 41 & 13.70 & 2.37 \\
\hline
\end{tabular}




\begin{tabular}{|c|c|c|c|c|c|c|c|c|c|}
\hline $\begin{array}{l}\text { Yazılı materyallerdeki çocuğumun ilgi alanına giren grafikleri } \\
\text { inceletme, bu grafiklerdeki bilgileri yorumlamasını sağlama }\end{array}$ & 58 & 19.30 & 69 & 23.00 & 100 & 33.30 & 73 & 24.30 & 2.87 \\
\hline \multicolumn{10}{|l|}{ Fen ve Teknoloji dersi becerilerini geliştirmek için; } \\
\hline Doğa olaylarını gözlemlemesini sağlama & 113 & 37.70 & 72 & 24.00 & 79 & 26.30 & 36 & 12.00 & 2.87 \\
\hline Canlıların büyüme, gelişme ve beslenmelerini gözlemlemesini sağlama & 105 & 35.00 & 70 & 23.30 & 87 & 29.00 & 38 & 12.70 & 2.81 \\
\hline $\begin{array}{l}\text { Fen bilgilerinin teknolojiye yansıdığı durumlara ve günlük yaşamda } \\
\text { kullanılan örneklere dikkatini çekme }\end{array}$ & 57 & 19.00 & 88 & 29.30 & 88 & 29.30 & 67 & 22.30 & 2.45 \\
\hline $\begin{array}{l}\text { Çevre sorunları ile ilgili sorumluluk ve bilinç geliştirmesine yardımcı } \\
\text { olma }\end{array}$ & 156 & 52.00 & 78 & 26.00 & 50 & 16.70 & 16 & 5.30 & 3.25 \\
\hline
\end{tabular}

Tablo 2'de görüldüğü gibi velilerin çocuklarının derslerine yardım etmek için "her zaman" ve "çoğu zaman" yaptıklarını ifade ettikleri destekleme çalışmaları daha çok genel akademik destekleme çalışmaları olmuştur. Velilerin büyük bir çoğunluğunun "her zaman" ya da "çoğu zaman” yaptıkları yönünde en fazla görüş belirttikleri genel akademik destekleme çalışmaları çocuklarının proje ve performans ödevlerini takip etme, onları farklı öğrenme kaynaklarından araştırma yapmaya teşvik etme, dersleri ile ilgili test çözmelerini sağlama, evde uygun öğrenme ortamları hazırlama, okul kurslarına gönderme ve yaptığı ödevler ile sınavlardan aldığı sonuçları izlemedir. Bu destekleme çalışmalarını velilerin yaklaşık üçte ikisi tarafından "her zaman" ya da "çoğu zaman" yaparım şeklinde ifade edilen çocuğumun içinde bulunduğu yaş grubunun gelişimsel ve psikolojik özellikleri hakkında bilgi edinme, "Neden", "nasıl" ve "ne yapmalı" gibi sorular sormaya ve sorgulama yapmaya teşvik etme ve çocuğumun öğrenmelerinde ilgi, yetenek ve eğilimlerini dikkate almasını sağlama şeklindeki genel destekleme çalışmaları takip etmektedir. Çocuklarına özel ders aldırma, çocukların okulda gördükleri derslerin evde birlikte tekrarını yapma, başarılı arkadaşları ile grup oluşturarak birlikte çalışmasını sağlama ve çocuğunun eğitimini nasıl destekleyebileceğiyle ilgili bilgi edinmek için farklı kaynaklardan yararlanma davranışları ise velilerin hiç bir zaman yapmadıklarını veya bazen yaptıklarını belirttikleri destekleme çalışmalar olmuştur. Tablo 1'de görüldüğü gibi veliler çocuklarının Sosyal bilimler, Türkçe, Fen ve teknoloji ile Matematik derslerine yönelik özel destekleme çalışmalarını daha az yapmaktadırlar. Sosyal bilimler ve Türkçe gibi sözel derslere yönelik en fazla yaptıklarını ifade ettikleri destekleme çalışması aile ortamında ve diğer ortamlarda çocuklarını konuşmaya cesaretlendirerek duygu ve düşüncelerini rahatça ifade etmelerini sağlamaktır. Velilerin çoğunun "bazen" yaptıklarını ya da "hiçbir zaman" yapmadıklarını belirttikleri etkinlik ise çocuklarına gezdikleri yerlere ya da okuduğu kitaplara yönelik kendisine ilginç gelen kişi, olay ve yerler hakkındaki düşüncelerini yazma çalışmaları yaptırma olmuştur. Matematik becerilerini geliştirmek için velilerin çoğu tarafından "her zaman" ya da "çoğu zaman" yaptıkları ifade edilen destekleme çalışması günlük yaşantılarındaki olaylarda matematiğe ilişkin sorular sormadır. Bu becerileri desteklemede en az (bazen ya da hiçbir zaman) yapılan etkinlik ise matematiği eğlenceli hale getirmek için çocuğuyla sudoku vb. bilmeceleri çözme olmuştur. Fen ve teknoloji dersi becerilerini geliştirmede fen bilgilerinin teknolojiye yansıdığı durumlara ve günlük yaşamda kullanılan örneklerine dikkatinin çekilmesini sağlama etkinliğinin velilerin çoğunluğu tarafından en az yapılan ya da hiç yapılmayan destekleme çalışması olduğu görülmüştür. Velilerin çoğunluğu tarafından çocuklarının bu derse yönelik becerilerini geliştirmede "her zaman" ya da "çoğu zaman" yapılan olarak ifade edilen etkinlik ise onların çevre sorunları ile ilgili sorumluluk ve bilinç geliştirmelerine yardımcı olmadır. Velilerle çocuklarının derslerine ilişkin hangi akademik destekleme etkinliklerini yaptıklarını belirlemeye yönelik görüşmeler de gerçekleştirilmiştir. Yapılan görüşmelerden elde edilen görüşler ve bu görüşlere ait frekans dağılımları Tablo 3'te verilmiştir.

Tablo 3'te görüldüğü gibi velilerden30'u çocuğunu konu ile ilgili soru çözmesini sağladıklarını; 12'si birlikte konu tekrarı yaptıklarını; 10'u ise ödev kontrolü yaptıklarını belirtmişlerdir. Soru çözdürme ve konu tekrarı çalışmalarına yönelik velilerin görüşlerinden bazıları şu şekildedir:

V1: "Bütün derslerine yardımcı olmaya çalışıyorum ama özellikle temel derslerine yönelik soru çözmesini sağlıyorum. Bu soruları bazen ona aldığım test kitaplarından yapıyor bazen de internetten yararlanıyorum ona uygun testler buluyorum zaman tutarak kendini değerlendirebileceği..."

V11: “... Konu tekrarının ardından o konunun pekişmesi için konu ile ilgili soru çözmesinin çok önemli olduğunu düşünüyorum. O nedenle mümkün olduğunda konu tekrarından ya hemen sonra ya da birkaç gün sonra test çözdürüyorum ya da kendim uygun sorular yazıyorum ona."

V14: “... Mesela Türkçe öğretmeni çok güzel bir şey demiş onlara. Her hafta işledikleri konu ile ilgili 10 tane soru çözeceksiniz ve bu soruların cevaplarınız anneniz ya da babanız kontrol edip imza atacak hafta sonu. Pazartesi de öğretmenlerine gösteriyorlar. Ben de her hafta sonu yaptı mı diye kontrol ediyorum". 
Tablo 3.

Velilerin Gerçekleştirdikleri Akademik Destekleme Çalışmalarına ilişkin Görüşleri*

\begin{tabular}{|c|c|c|c|c|c|c|c|c|}
\hline Tema & Kodlar & 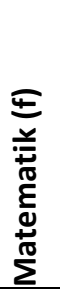 & 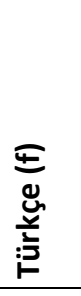 & 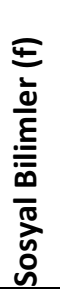 & 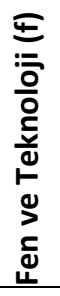 & 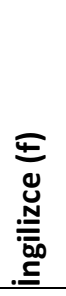 & 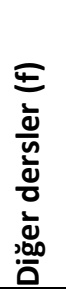 & $\begin{array}{l}\Phi \\
\underset{\varepsilon}{E} \\
\frac{\pi}{0} \\
\stackrel{0}{0}\end{array}$ \\
\hline Velilerin & Konu ile ilgili soru çözmesini sağlama & 22 & 15 & 9 & 16 & 9 & 3 & 30 \\
\hline Akademik & Birlikte konu tekrarı yapma & 7 & 7 & 7 & 6 & 3 & 3 & 12 \\
\hline Destekleme & Bireysel kitap okuma & & 11 & & & & & 11 \\
\hline \multirow[t]{6}{*}{ Çalışmaları } & Ödev kontrolü yapma & 3 & 6 & 3 & 5 & 9 & 2 & 10 \\
\hline & Ders konusuna ilişkin sohbet etme & - & 3 & 4 & - & 1 & - & 6 \\
\hline & Araştırma yapma & 2 & 1 & 5 & 2 & 3 & - & 5 \\
\hline & Birlikte kitap okuma & - & 4 & - & - & - & - & 4 \\
\hline & Kelime dağarcığını zenginleştirme & - & 2 & - & - & 4 & - & 4 \\
\hline & Eğitsel oyunlar oynama & 3 & 2 & 1 & 1 & - & - & 3 \\
\hline
\end{tabular}

*Aynı velinin derslere göre görüşleri her ders için ayrı gösterilmiştir.

V25: “... Bize ve çocuklara sınıf öğretmenimiz her gün konu tekrarı yapın diyor. Ben de buna dikkat etmeye çalışıyorum..."

V34: "Konu tekrarı gerçekten çok önemli. Biz babamız akşam eve gelmeden yani akşam yemeğinden önce genelde o gün okulda gördükleri derslerin genel bir tekrarını yapmaya dikkat ediyoruz birlikte".

V40: "Açıkçası ben çok ilgilenemiyorum çocuğumla dersleri konusunda. Ama diyorum ki sen ödevlerini yap bitir sonra gel bana göster. O da yapıp sonra bana gösteriyor olmuş mu diye."

V40: "Ben ödevlerin kontrol ediyorum. Ediyorum etmesine ama bazı dersler şu yanlış bu doğru olmuş diyemiyorum. Mesela İngilizce ödevini yaptın $\mathrm{mı}$ aç bir bakayım diyorum. Bakıyorum soruların cevaplarını yazmışsa işte ya da işaretlemeler yapmışsa tamam diyorum. Ama doğru mu yapmış yanlış mı onu çok bilmiyorum genelde...."

Velilerin görüşlerinde ifade ettikleri bazı destekleme çalışmalarının ise desteklenecek derse göre değiştiği bir başka deyişle ilgili dersin desteklenmesine özel gerçekleştirilen destekleme çalışmaları olduğu söylenebilir. 11 veli Türkçe dersi kapsamında verilen hikâye/roman kitaplarını çocuklarına evde okumalarını söylediklerini; 10 veli farklı derslere göre çocuklarının ödevlerini kontrol ettiklerini belirtmişlerdir. Veliler tarafından ödev kontrolünün en fazla yapıldığı ders İngilizce; en az yapıldığı ders ise Tablo 3'te görülen dersler dışındaki diğer dersler olmuştur. Velilerden altısı Türkçe, Sosyal bilimler ve İngilizce olarak farklı derslere yönelik birlikte ders konusuna ilişkin sohbet ettiklerini söylemişlerdir. Beş veli Tablo 3'te gösterilen diğer dersler dışındaki tüm derslere yönelik araştırma çalışmaları yaptırdıklarını belirtmişlerdir. Kitap okutma, ders konusuna ilişkin sohbet etme ve araştırma çalışmaları yaptıklarını ifade eden velilerin görüşlerinden bazıları aşağıda verilmiştir:

V7: "Benim izlediğimi bazı tarihi diziler var televizyonda. Tarihe de çok ilgi duyuyorum. İzlediğim dizilerdeki bazı konular çocuğumun sosyal bilgiler dersine gördüğü konulardan oluyor birlikte üzerine sohbet ediyoruz. Çok da keyif alıyoruz bundan".

V8: "Türkçe dersine öğretmenleri hikâye kitabı okuyun diyor ve çocuklardan okudukları bir kitabı sonra sınıfta anlatmalarını istiyor, soru da soruyor o kitaptan. Ben de eve gelince aç Türkçe dersi içi kitap oku biraz diyorum..."

Birlikte kitap okuma, kelime dağarcığını zenginleştirme, eğitsel oyunlar oynama veliler tarafından en az ifade edilen destekleme çalışmaları olmuştur. Dört veli Türkçe dersine yönelik becerilerini geliştirmek için birlikte kitap okuma çalışmaları yaptıklarını ifade etmişlerdir. Toplamda dört veli İngilizce ve/veya Türkçe derslerine yönelik birlikte kelime çalışmaları yaptıklarını; üç veli de farklı derslere yönelik çocuklarına eğitsel oyunlar oynattıklarını belirtmişlerdir. Bu destekleme çalışmalarını bazı veliler görüşlerinde şu şekilde ifade etmişlerdir: 
V2: "Yani genelde yaptıklarım genel destekleme çalışmaları. Her bir derse ilişkin yaptığım özel destekleme çalışmaları az. Ama Türkçe dersine faydası olsun diye birlikte okuma çalışmaları yapıyoruz. İkimiz yarım saat kitap okuyoruz mesela herkes kendi kitabını okuyor".

V18: “Kelime dağarcığını zenginleştirici oyunlar oynuyoruz biz birlikte. Bulmaca çözüyoruz, scrabble oynuyoruz. Ya da işte ne bileyim birbirimizin söylediği kelimelerin son harfleri ile kelime türetmece oynuyoruz".

Görüşmelerden elde edilen bulguların da anket bulgularını destekler nitelikte olduğu söylenebilir. Gerek anketlerden gerekse görüşmelerden elde edilen bulgular velilerin çocuklarının öğrenmelerini akademik anlamda destekleme çalışmalarında tüm derslere ilişkin gerçekleştirebilecekleri genel destekleme çalışmalarını daha fazla yaptıklarını; ancak her bir dersin özel amaçlarına ilişkin yapılan destekleme çalışmalarının ise çok az olduğunu göstermektedir. Özellikle velilerle gerçekleştirilen görüşmelerde sayısal derslere ilişkin gerçekleştirilen özel destekleme çalışmaları çok az veli tarafından ifade edilmiştir. Velilerin çoğunluğu ise çocuklarının öğrenmelerini akademik anlamda desteklemeye yönelik herhangi bir çalışma yapmadıklarından bahsetmişlerdir:

V1: "Akademik anlamda derken? ... Valla benim onun derslerine ilişkin çok bir bilgim yok. Ödevlerini yaptı mı diye kontrol ediyorum en fazla. Yoksa daha özel bir şey yapamıyorum zaten benim bilgim ona yeter mi ki?"

V12: “Yani genel şeyleri yapıyoruz işte. Ödev kontrolü, bazen işte anladığım derslerde görsel sanatlar, müzik öyle derslerinde yardımcı olmam gereken bir şeyler oluyorsa onları yapıyoruz birlikte. Matematik, Türkçe gibi asıl yardımcı olmak istediğim konularda hemen hemen hiç yardımcı olamıyorum"

V36:"Biz hiç yardımcı olamıyoruz. Ben de babası da yoğun çalışıyoruz. Zamanımız da çok yok o nedenle yeterince ilgilenemiyoruz".

\section{Velilerin Çocuklarının Öğrenmelerini Desteklemek İçin Gerçekleştirdikleri Güdüleyici Etkinliklere ilişkin Elde Edilen Bulgular}

Velilerin çocuklarının öğrenmelerini desteklemede onların etkili, keyif alarak ve neden öğrendiklerinin farkında olarak öğrenmelerini sağlamalarında onları öğrenmeye karşı güdüleyecek destekleme çalışmalarını gerçekleştirmeleri önemli olmaktadır. Tablo 4'te velilerin çocuklarını öğrenmeye karşı güdülemek için gerçekleştirdikleri etkinliklere ilişkin görüşlerine yönelik elde edilen bulgular gösterilmiştir.

Tablo 4'te görüldüğü gibi çocuklarını öğrenmeye güdülemek için velilerin çoğunluğu tarafından "her zaman” ya da "çoğu zaman" olarak gerçekleştirdikleri ifade edilen destekleme çalışmaları ders çalışma sorumluluklarını yerine getirdiğinde güzel sözlerle onu övme, başarısız olduğu durumlarda başarılı olacağını söyleyerek onu yüreklendirme ve okulda gününün nasıl geçtiği hakkında onunla sohbet etmedir. Velilerin çoğunluğu tarafından "bazen" yaptıkları ya da "hiçbir zaman" yapmadıkları yönünde ifade edilen güdüleme çalışmaları ise çocuğunun kompozisyon, şiir, resim gibi çalışmalarını teşvik amacıla evin görünen yerlerine asma ve ders çalışma sorumluluklarını yerine getirdiğinde onu sevdiği bir etkinliğe götürme olmuştur. Velilerle yapılan görüşmelerde onlara çocuklarını öğrenmeye güdülemek için ne tür destekleme çalışmaları yaptıkları da sorulmuştur. Yapılan görüşmelerden elde edilen bulgular ve bu görüşlere ait frekans dağılımları Tablo 5 'te verilmiştir.

Tablo 5'te görüldüğü gibi velilerin en fazla gerçekleştirdikleri güdüleme çalışmaları çocuklarının başarılarını övme ve başarılarını ödüllendirmedir. 30 veli çocuğu bir sınavda ya da bir ödevde başarılı olduğu zaman onu ödüllendirdiğini; 25 veli de ona takdir edici konuşmalar yaptığını ifade etmiştir. Bu konuda ifade edilen veli görüşlerinden bazıları şu şekildedir:

V8: “ ....notlarını yüksek getirir başarılı olursa tatil gibi, denize gitmek gibi ya da sevdiği istediği bir şeyi almak için söz veririz ve yaparız."

V10:“yüksek bir not aldığında ödüllendiriyorum tabi. Doğum gününde hediye alarak ya da gezmeye götürerek yapıyorum genelde".

V17:“Başarması gereken bir işi uğraşıp başarması durumunda söz verdiğim ve çok istediği bir şeyi ona alırım”. 
V20: "Başarılı olduğunda kitap alarak ya da özel geziler yaparak ödüllendiriyorum”.

V27: “...yani her zaman bir hediye almamız ya da onun istediği bir şeyi yapmamı mümkün olmuyor tabi. Ama ben her başarısında onu takdir edici sözler söylemeyi ihmal etmiyorum. Başarılı olduğunda aferin diyorum, benim oğluma da bu yakışırdı zaten diyorum...."

V36: “Çocuğumu güdülemekte ona bir işi başardığında övgü dolu sözler söylemenin önemli olduğunu düşünüyorum ama tabi abartmadan. Benim kızım çok duygusal o nedenle bir işi başardığında övülmek onun daha çok çalışmasını sağlıyor. Bravo yavrum hep böyle devam et çalışmalarının karşılığını şimdi olduğu gibi ileride de çok fazlasıyla alacaksın diyorum mesela..."

Tablo 4.

Ortaokul Öğrenci Velilerinin Gerçekleştirdikleri Güdüleme Etkinliklerine Yönelik Görüşleri

\begin{tabular}{|c|c|c|c|c|c|c|c|c|c|}
\hline \multirow[b]{2}{*}{ Destekleme Çalışmaları } & \multicolumn{4}{|c|}{$\begin{array}{l}\text { Çoğu } \\
\text { zaman }\end{array}$} & \multicolumn{2}{|c|}{ Bazen } & \multicolumn{2}{|c|}{$\begin{array}{l}\text { Hiçbir } \\
\text { zaman }\end{array}$} & \multirow{2}{*}{ 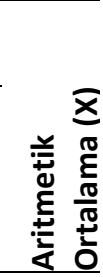 } \\
\hline & f & $\%$ & f & $\%$ & f & $\%$ & f & $\%$ & \\
\hline $\begin{array}{l}\text { Güncel olaylar hakkında konuşarak bu olaylar ile } \\
\text { derslerde öğrendikleri arasında ilişki kurmasını } \\
\text { sağlama }\end{array}$ & 122 & 40.70 & 75 & 25.00 & 76 & 25.30 & 27 & 9.00 & 2.97 \\
\hline $\begin{array}{l}\text { Okuldan eve geldiğinde okulda gününün nasıl } \\
\text { geçtiği hakkında sohbet etme }\end{array}$ & 198 & 66.00 & 56 & 18.70 & 38 & 12.70 & 8 & 2.70 & 3.48 \\
\hline $\begin{array}{l}\text { Yanında kitap ve gazete okuyarak onu da } \\
\text { okumaya teşvik etme }\end{array}$ & 115 & 38.30 & 74 & 24.70 & 90 & 30.00 & 21 & 7.00 & 2.94 \\
\hline $\begin{array}{l}\text { Başarısız olması halinde, gayret ederse başarılı } \\
\text { olacağını söyleyerek onu yüreklendirme }\end{array}$ & 224 & 74.70 & 41 & 13.70 & 23 & 7.70 & 12 & 4.00 & 3.59 \\
\hline $\begin{array}{l}\text { Ders çalışma sorumluluklarını yerine getirdiğinde } \\
\text { güzel sözlerle onu övme }\end{array}$ & 214 & 71.30 & 60 & 20.00 & 23 & 7.70 & 3 & 1.00 & 3.62 \\
\hline $\begin{array}{l}\text { Sadece başarılarını değil, çabalarını da } \\
\text { ödüllendirme }\end{array}$ & 152 & 50.70 & 65 & 21.70 & 77 & 25.70 & 5 & 2.00 & 3.21 \\
\hline $\begin{array}{l}\text { Ders çalışma sorumluluklarını yerine getirdiğinde } \\
\text { onu sevdiği bir etkinliğe götürme }\end{array}$ & 105 & 35.00 & 64 & 21.30 & 88 & 29.30 & 43 & 14.30 & 2.77 \\
\hline $\begin{array}{l}\text { Yardım almadan kendi kendine bir şeyler } \\
\text { başarmasına fırsat verme }\end{array}$ & 187 & 62.30 & 79 & 26.30 & 30 & 10.00 & 4 & 1.30 & 3.50 \\
\hline $\begin{array}{l}\text { Kompozisyon, şiir, resim gibi çalışmalarını teşvik } \\
\text { amacıyla evin görünen bir yerine asma }\end{array}$ & 86 & 28.70 & 78 & 26.00 & 87 & 29.00 & 49 & 16.30 & 2.67 \\
\hline
\end{tabular}

Tablo 5.

Velilerin Gerçekleştirdikleri Güdüleyici Destekleme Çalışmalarına iliş̧kin Görüşleri

\begin{tabular}{lll}
\hline Tema & Kodlar & f \\
\hline Güdüleyici Destekleme & Başarılarını ödüllendirme & 30 \\
Çalışmaları & Başarılarını övme & 25 \\
& Eğitimin-öğrenmenin faydaları hakkında konuşma & 20 \\
& Başarılı olduğuna-olacağına yönelik özgüvenini geliştirme & 13 \\
& Kendi öğrenme amaçlarını belirlemesini sağlama & 7 \\
\hline
\end{tabular}

İkinci sırada veliler tarafından çocuklarını güdülemeye yönelik en fazla ifade edilen diğer destekleme çalışmaları ise çocuğuyla eğitimin-öğrenmenin faydaları hakkında konuşma ve onun başarılı olduğuna-olacağına ilişkin özgüvenini geliştirme olmuştur. Velilerden 20'si öğrenmenin neden önemli olduğu ve öğrendiklerinin kendisine sağlayacağı yararların neler olacağı konularında zaman zaman konuşmalar yaptıklarını ifade etmişlerdir. On üç veli ise çocuğunu başarılı olduğuna ya da isterse başarılı olabileceğine inanmasını sağlamanın çok önemli olduğunu belirtmişlerdir. Bu destekleme çalışmalarına yönelik bazı velilerin görüşleri şu şekildedir: 
V4: "Ben ödüllendirmeyi her zaman yapmıyorum. Yaptığım zamanlarda da öncelikle bir öğrenci olarak çalışmanın onun görevi olduğunu belirtiyorum ve öğrendiklerinin ileride ona sağlayacağı faydalardan bahsediyorum. Çalıştığında bu öğrenmelerinin ileriki yıllarında onun daha rahat bir yaşam sürmesinde önemli olacağını, çevresinde saygın bir insan olmasında ve kültürlü bir insan olmasında öğrenmenin öneminden bahsediyorum".

V27:“Çocuğumla öğrenmelerinin kendine ve topluma sağlayacağı faydalardan bahsediyorum. Kendine faydaları olduğu gibi topluma da faydalı bir birey olmasında öğrenmenin çok önemli olduğunu söylüyor ve örneklendiriyorum. Mesela..."

V34:"Bence çocuğumun başarılı olabilmesi için öncelikle kendisinin buna inanması gerekiyor. O nedenle sadece başarılı olduğu durumlarda değil başarısız olduğu durumlarda da konuşuyorum onunla. Hatalarını görmesini ve eğer dikkat ederse başaramayacağı hiç birşey olmadığını söylüyorum ona".

V40:“Benim oğlum bazı derslere hiç çalışmıyor. Neden çalışmıyorsun diyorum e zaten o dersi anlamıyorum ki diyor. Ben de diyorum önce bir kendine güven yapabileceğine inan. Sen bir çalış bakalım oluyor mu olmuyor mu diyorum. Anlamadığın yerleri de öğretmenine sor derste diyorum".

Velilerden sadece yedisi ise çocuklarının öğrenmeye karşı güdülenmelerinde onların kendi öğrenme amaçlarını belirlemelerini sağladıklarını ifade etmişlerdir. İki veli görüşlerini şu şekilde ifade etmiştir:

V19: "Benim oğlumun bir hedefi var o da pilot olmak. Diyorum ki ben ona çalışırsan bu öğrenmelerinin karşıı̆ı̆ında ileride istediğin mesleği yapabilir pilot olabilirsin diyorum. Çünkü pilot olabilmek için öncelikle üniversite sınavlarına girmen gerekecek ve üniversite sınavlarında başarılı olman da öğrenmelerine bağlı diyorum".

V31:“Kızım çok hırslı bir çocuk benim ve derslerde başarılı olmak onun için çok önemli. Ben de diyorum ki neden öğrenmek senin için önemli? Öğrenince ne olacak ne değişecek hayatında bunu bir düşün diyorum. Bu sene devletin bursluluk sınavına girecek mesela o sınavı kazanmak da çok önemli onun için. İşte o sınavda başarılı olmak, sınavlarında yüksek not almak için çok çalışıyorum anne ben diyor. Kendi belirliyor yani neden çalıştığını aslında. “

Velilerin görüşmelerde gerçekleştirdiklerini belirttikleri güdüleme çalışmalarından olan çocuğunu sevdiği bir etkinliğe ya da gezmeye götürmenin anketten elde edilen bulgularla uyuşmadığı söylenebilir. Bu destekleme çalışması veli görüşlerinde en fazla belirtilen ifadelerden biri olmuş ancak anket bulgularında Ders çalışma sorumluluklarını yerine getirdiğinde onu sevdiği bir etkinliğe götürme etkinliği veliler tarafından "hiçbir zaman" olarak en fazla belirtilen destekleme çalışması olmuştur. Bununla birlikte ankette bu destekleme çalışmasına toplam veli sayısı içerisinde hiç bir zaman şeklinde ifade eden veli sayısının az olması bu bağlamda her iki ölçme aracından elde edilen bulgularda dikkat çekici bir uyuşmazlığın olmadığını göstermektedir. Genel olarak ise velilerin çocuklarının öğrenmelerini destekleme için gerçekleştirdikleri güdüleme etkinliklerine ilişkin anket ve görüşmeden elde edilen verilerin birbirini destekler nitelikte olduğu söylenebilir.

\section{Velilerin Çocuklarının Öğrenmelerini Desteklemek İçin Onların Eğitimlerinde Etkili Olabilecek Kişiler ile Gerçekleştirdikleri Etkinliklere İlişkin Elde Edilen Bulgular}

Velilerin çocuklarının öğrenmelerini desteklemede kullanabilecekleri bir diğer destekleme çalışması çocuğunun eğitiminde etkili olabilecek diğer kişilerle ve kurumlar ile gerçekleştirdikleri etkinliklerdir. Bu kişiler çocuğunun arkadaşları, okul idaresi-öğretmenler, Milli Eğitim Bakanlığı, Milli Eğitim Müdürlüğü, diğer öğrencilerin velileri gibi geniş kapsamda olabilir. Tablo 6'da velilerin çocuklarının eğitiminde etkili olabileceği kişilerle gerçekleştirdikleri etkinlikler sunulmuştur:

Tablo 6’da görüldüğü gibi velilerin çoğunluğu tarafından "her zaman” ya da "çoğu zaman” gerçekleştirildiği ifade edilen destekleme çalışmaları okul toplantılarına katılmak ve bu toplantılarda olumlu-olumsuz düşüncelerini açıkça söylemek olmuştur. Velilerin yarısından fazlasının "bazen" yaptıkları ya da "hiç bir zaman" yapmadıkları destekleme çalışmaları ise MEB tarafından düzenlenen aile eğitimi kurslarına katılma, çocuğunun sınıfındaki velilerle tanışıp çocuklarının dersleri hakkında bilgi ve fikir alışverişinde bulunma, velilere yönelik düzenlenen bilgilendirici program, konferans ve seminerlere katılma, çocuğuyla ilgili bilgi almak için öğretmeniyle görüşme, öğretmenden ders programları ve işlenecek konular hakkında bilgi alma ve bir ders konusunda çocuğunu desteklemede yetersiz kaldığında başkalarından yardım isteme olarak belirtilmiştir. 
Tablo 6.

Velilerin Çocuğunun Eğitiminde Etkili Olabilecek Kişiler ve Kurumlarla Gerçekleştirdikleri Etkinliklere Yönelik Görüşleri

\begin{tabular}{|c|c|c|c|c|c|c|c|c|c|}
\hline \multirow[b]{2}{*}{ Destekleme Çalışmaları } & \multicolumn{2}{|c|}{ Her zaman } & \multicolumn{2}{|c|}{$\begin{array}{c}\text { Çoğu } \\
\text { zaman }\end{array}$} & \multicolumn{2}{|c|}{ Bazen } & \multicolumn{2}{|c|}{$\begin{array}{l}\text { Hiçbir } \\
\text { zaman }\end{array}$} & \multirow{2}{*}{ 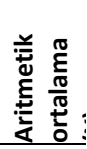 } \\
\hline & f & $\%$ & f & $\%$ & $\mathbf{f}$ & $\%$ & f & $\%$ & \\
\hline Okul toplantılarına katılma & 212 & 70.70 & 54 & 18.00 & 28 & 9.30 & 6 & 2.00 & 3.57 \\
\hline Okul toplantılarında olumlu ve olumsuz görüşlerimi açıkça söyleme & 155 & 51.70 & 85 & 28.30 & 48 & 16.00 & 12 & 4.00 & 3.28 \\
\hline $\begin{array}{l}\text { Toplantıya katılamadığım zamanlarda öğretmenle görüşmeye } \\
\text { çalışma }\end{array}$ & 152 & 50.70 & 70 & 23.30 & 64 & 21.30 & 14 & 4.70 & 3.20 \\
\hline Çocuğumla ilgili bilgi almak için öğretmeniyle görüşme & 85 & 28.30 & 64 & 21.30 & 110 & 36.70 & 41 & 13.70 & 2.64 \\
\hline $\begin{array}{l}\text { Bir ders konusunda çocuğumu desteklemede yetersiz kaldığımda } \\
\text { başkalarından yardım isteme }\end{array}$ & 80 & 26.70 & 73 & 24.30 & 104 & 34.70 & 43 & 14.30 & 2.63 \\
\hline Çocuğumun gelişim özellikleri hakkında bilgi alma & 120 & 40.00 & 72 & 24.00 & 79 & 26.30 & 29 & 9.70 & 2.94 \\
\hline Öğretmenle sadece çocuğum düşük not aldığında görüşme & 31 & 10.30 & 15 & 5.00 & 64 & 21.30 & 190 & 63.30 & 1.62 \\
\hline $\begin{array}{l}\text { Öğretmenle sadece çocuğumla ilgili olumsuz bir durum hakkında } \\
\text { konuşmak için okula çağrıldığım zaman görüşme }\end{array}$ & 45 & 15.00 & 28 & 9.30 & 73 & 24.30 & 154 & 51.30 & 1.88 \\
\hline $\begin{array}{l}\text { Başarısını desteklemek için neler yapmam gerektiğini } \\
\text { öğretmenleriyle görüşme }\end{array}$ & 99 & 33.00 & 76 & 25.30 & 92 & 30.70 & 33 & 11.00 & 2.80 \\
\hline $\begin{array}{l}\text { Öğretmenden, izlediği eğitim yaklaşımı konusunda beni } \\
\text { aydınlatmasını isteme }\end{array}$ & 111 & 37.00 & 82 & 27.30 & 80 & 26.70 & 27 & 9.00 & 2.92 \\
\hline $\begin{array}{l}\text { Iyi-kötü, zayıf-güçlü yanları hakkında bilgi sahibi olmak hem de } \\
\text { öğretmeni bilgilendirmek amacıyla görüşme }\end{array}$ & 111 & 37.00 & 80 & 26.70 & 87 & 29.00 & 22 & 7.30 & 2.93 \\
\hline $\begin{array}{l}\text { Öğretmeninden, ders programları ve işlenecek konular hakkında } \\
\text { bilgi alma }\end{array}$ & 67 & 22.30 & 60 & 20.00 & 108 & 36.00 & 65 & 21.70 & 2.43 \\
\hline $\begin{array}{l}\text { Velilere yönelik düzenlenen bilgilendirici program, konferans ve } \\
\text { seminerlere katılma }\end{array}$ & 82 & 27.30 & 62 & 20.70 & 104 & 34.70 & 52 & 17.30 & 2.58 \\
\hline MEB tarafından yayınlanmış olan farklı yayınları takip etme & 98 & 32.70 & 72 & 24.00 & 85 & 28.30 & 45 & 15.00 & 2.74 \\
\hline MEB tarafından gerçekleştirilen aile eğitimi kurslarına katılma & 54 & 18.00 & 45 & 15.00 & 84 & 28.00 & 117 & 39.00 & 2.12 \\
\hline $\begin{array}{l}\text { Çocuğumun sınıfındaki velilerle tanışıp, çocuklarımızın dersleri } \\
\text { hakkında bilgi ve fikir alışverişinde bulunma }\end{array}$ & 61 & 20.30 & 65 & 21.70 & 119 & 39.70 & 55 & 18.30 & 2.44 \\
\hline
\end{tabular}

Velilerle yapılan görüşmelerde onlara çocuklarının eğitimlerinde etkili olabilecek kişi ve kurumlarla birlikte ne tür çalışmalar gerçekleştirdikleri sorulmuştur. Yapılan görüşmelerden elde edilen görüşler ve bu görüşlere ait frekans dağılımları Tablo 7'de verilmiştir.

Tablo 7.

Velilerin Çocuğunun Eğitiminde Etkili Olabilecek Kişiler ve Kurumlarla Gerçekleştirdikleri Etkinliklere Yönelik Görüşleri

\begin{tabular}{llr}
\hline Tema & Kodlar & $\mathbf{f}$ \\
\hline Paydaşlarla gerçekleştirilen & Veli toplantılarına katılma & 30 \\
destekleme çalışmaları & Çocuğu ile ilgili bir sorun durumunda okula çağrıldığında & 15 \\
& gitme & \\
& Veli görüşme saatlerinde görüşmeye gelme & 7 \\
\hline
\end{tabular}

Tablo 7'de görüldüğü gibi velilerle yapılan görüşmelerde de 25 veli tarafından en fazla ifade edilen destekleme çalışması veli toplantılarına katılmak olmuştur. Bu konuda görüş belirten velilerden bazılarının görüşleri şunlardır:

V21: "Veli toplantılarına düzenli katılmaya çalışıyorum önemli çünkü. Veli toplantılarına katılamadığımda bazen hastane işlerim oluyor çünkü o zaman öğretmenlerle birebir görüşmek için görüşme saatlerinde okula gidiyorum".

V32: "Veli toplantıları özellikle genel veli toplantılarını kaçırmıyorum. Bu toplantılarda bütün öğretmenleri bir arada görebiliyorsunuz. Çocuğunuzun notlarını öğreniyor ve çocuğunuzun hangi dersten özel bir durumu var ise söylemeniz için bütün öğretmenler orada oluyor aslında".

Bunun yanında veli toplantılarına özellikle katılmadığını ifade eden veliler de olmuştur. íki velinin veli toplantıları konusundaki görüşleri şu şekildedir: 
V37: "Ben katılmıyorum veli toplantılarına çünkü hep aynı şeyler konuşuluyor. Özellikle sadece sınıf öğretmeninin olduğu veli toplantılarında mutlaka konu okul aidatına geliyor. Sanki sırf bunu söylemek için çağırıyorlarmış gibi geliyor bana".

V43: "Valla her zaman katılmıyorum veli toplantılarına. Benim oğlan biraz yaramaz ne zaman gitsem hep çocuktan şikayet duyuyorum bu da beni daha çok sinirlendiriyor o nedenle her zaman gitmiyorum".

Yukarıdaki ifadelerden anlaşılacağı gibi bazı veliler çocuğu ile ilgili olumsuz bir durum nedeniyle okula çağrıldıklarında gitmediklerini söylerken; 15 veli ise böyle bir durumda okula gidip okul idaresi ya da öğretmenle görüştüklerini belirtmişlerdir. Velilerin bu konudaki açıklamalarından örnek alıntılar şöyledir:

V8:“Benim oğlum geçen sene sınıfta kaldı. Hem derslerine çalışmıyor hem de yaramaz. Okul idaresi dedi ki bu sene sıkı tutmazsak gene kalır sınıfta. O nedenle sağ olsunlar onlar (okul idaresi - öğretmen) ilgileniyor. $E$ ben de onlar olumsuz bir durumda beni çağırdıklarında gidiyorum kesinlikle okula.".

V13:“Ya bazen çocuklarımız ergenliğin de etkisi ile çok fazla yaramazlık yapıp öğretmenlerini üzüyorlar. Böyle bir durumda öğretmen bana gel derse ben hemen okula gidiyorum. Olan biteni sadece çocuğumdan değil öğretmende de dinleyince daha iyi görebiliyorum yani ne olduğunu..."

Sadece yedi veli ise veli görüşme saatlerinde kendi istekleri ile öğretmenle görüşmek için geldiklerini ifade etmişlerdir. Bu velilerin görüşlerinden bazıları şunlardır:

V8:“Ben çocuklarımın eğitimlerine hep çok önem vermişimdir. O nedenle bütün öğretmenlerin veli görüşme saatlerini aldım. 1,5 ayda bir gidiyorum yanlarına onların çağırmalarını beklemeden. Soruyorum var mı acaba çocuğumla ilgili bilmem gereken bir şey diye."

V13:“Veli toplantılarında her zaman çocuğunuzla ilgili özel konuşamıyorsunuz. Yani olmuyor tüm velilerin içinde konuşmak istemiyorsunuz bazen. Bazen de öğretmenin o kadar vakti de olmuyor. Ama bizim sınıf öğretmenimiz bizi veli görüşme saatlerinde konusunda bilgilendirdi. Bu saatlerde tüm veliler gitmediği için daha sakin oluyor ben de gidip çocuğumla ilgili bilgi alabiliyorum daha rahat bir şekilde..."

Velilerin çocuklarının eğitiminde etkili olabileceği kişiler ve kurumlarla gerçekleştirdikleri etkinliklere yönelik görüşlerinden elde edilen bulgular genel olarak değerlendirildiğinde dikkati çeken önemli bir noktanın velilerin çocuklarının öğrenmelerini desteklemek için işbirliği içerisinde oldukları kişinin genellikle sadece öğretmenler ve okul idaresi olduğu görülmektedir. Başka bir deyişle çoğunlukla çocuklarının öğrenmelerini destekleme amaçlı diğer sınıf velileri ile iletişim kurmadıkları, çocuklarına arkadaşları ile okul dışı birlikte çalışabilecek öğrenme ortamları oluşturmadıkları ve MEB'in kendilerine sunduğu eğitim olanaklarından çok fazla yararlanmadıkları söylenebilir. Dikkat çeken bir diğer nokta ise velilerin öğretmenler ile görüşmelerini daha çok veli toplantıları şeklinde gerçekleştirmeyi tercih etmeleri, kendi istekleri ile birebir görüşmeler yapmamaktadırlar.

\section{Tartışma, Sonuç ve Öneriler}

Çocuğun öğrenme sürecinin doğumuyla birlikte başlaması ve zamanının önemli bir kısmını ailesi ile geçirmesi nedeniyle ailenin çocuğun eğitimini ve öğrenmelerini desteklemesi büyük bir önem taşımaktadır. Bu araştırmada da velilerin çocuklarının öğrenmelerini nasıl ve ne kadar destekleyebildiklerinin ortaya konulması amaçlanmıştır. Araştırmada veli kavramı ile kastedilen çocuğun eğitiminden sorumlu olan kişi/kişiler olarak ele alınmakla birlikte araştırmanın tüm katılımcılarının planlanmamış olmasına rağmen annelerden oluştuğu görülmüştür. Karşılaşılan bu durumdan hareketle çocuklarının öğrenmelerini destekleme sorumluluğunun çoğunlukla annelerde olduğu söylenebilir. Alanyazında aile katılımına yönelik yapılan çalışmalarda da çocuklarının evde yapılan destekleme çalışmalarında daha çok anneleri ile birlikte çalıştıkları görülmektedir (Edwards \& Gillies, 2011; Jezierski \& Glenda, 2017; Wall, 2013). Yapılan bu araştırmanın katılımcılarının anneler olmasının bir başka nedeni de annelerin büyük bir çoğunluğunun ev hanımı olması başka bir deyişle çalışmıyor olması olabilir. Alanyazındaki araştırmaların ise bu konuda farklı sonuçlar ortaya koyduğu görülmektedir. Göktürk ve Dinçkal (2018) çalışmalarında çocuklarının eğitimleri ile daha fazla ilgilenen velilerin çalışmayan ya da az çalışan veliler olduğunu belirtmişlerdir.

Araştırmadan elde edilen bulgular doğrultusunda velilerin genel akademik destekleme çalışmalarını derslere yönelik daha detaylı ve özel akademik destekleme çalışmalarına göre daha fazla uygulayabildikleri söylenebilir. Alanyazındaki ailelerin eğitim düzeyleri ile aile katılım düzeyleri arasında pozitif yönde bir ilişki olduğunu 
gösteren araştırmalar (Argon \& Kıyıcı, 2012; Bæck, 2010; Hornby \& Blackwell, 2018;Kotaman, 2008; Lareau, 2011;) dikkate alındığında velilerin genel akademik destekleme çalışmalarını nispeten daha fazla gerçekleştirmelerinde eğitim düzeylerinin etkili olabileceğini düşündürmektedir. Bununla birlikte araştırmada kullanılan ankette yer alan derslere yönelik akademik destekleme çalışmalarına ilişkin maddeler ilgili derse ilişkin ilkokul düzeyinde temel bilgi ve beceri gerektiren destekleme etkinliklerini kapsamaktadır. Bu durum araştırmanın katılımcıları olan velilerin de çoğunluğunun en az ilkokul mezunu olduğu göz önüne alındığında velilerin bu akademik destekleme çalışmalarını derslere yönelik bilgi ve becerilerinden kaynaklanan eksikliklerinden ziyade derslere ilişkin bu ayrıntılı destekleme çalışmalarını nasıl gerçekleştirebileceklerini bilmemelerinden kaynaklanıyor olma olasıı̆̆ını güçlendirmektedir. Öz (1983) de velilerle gerçekleştirdiği araştırmasında velilerin çocuklarının öğrenmelerini desteklemek istediklerini ancak nasıl destekleyebileceklerini bilmemeleri nedeniyle onlara yardımcı olamadıklarını ifade etmiştir (Porsuk \& Kunt, 2012). Gündüz (2018) de yaptığı çalışmasında sosyal ağ üzerinden gerçekleştirilen veli koçluğu araştırmasında velilerin araştırmacıdan destekleme çalışması olarak en fazla beklentileri olan konulardan birinin de ders konularına yönelik çocuklarını nasıl destekleyebileceklerine ilişkin rehberlik edilmesi olduğunu belirtmiştir. Caputo (2007), Lareau (2011) ve Tulviste ve Kikas (2010) da ailelerin genelde aile katılımını nasıl gerçekleştirebilecekleri özelde ise çocuklarının ödevlerine nasıl yardımcı olabileceklerini bilme arzularının yüksek olduğunu belirtmektedirler.

Araştırmada elde edilen önemli bulgulardan birisi de velilerin çocuklarının öğrenmelerini desteklemede güdüleyici etkinlikleri akademik destekleme çalışmalarına ve çocuklarının öğrenmelerini etkileyebilecek diğer kişilerle işbirliği yaptıkları etkinliklere göre daha fazla gerçekleştirmeleridir. William, Swift, Williams ve Daal (2017) da velilerin okul ödevlerine katılımı ile öğrencilerin özyeterliklerini artırma isimli çalışmalarında velilerin matematik yeterliklerini gerektiren öğretimsel tekniklerden çok çocuklarını cesaretlendirme, model olma ve güdülemeye ilişkin destekleme çalışmalarını ön plana çıkarmanın daha etkili sonuçlar verdiğini belirtmişlerdir. Velilerin güdüleyici destekleme etkinliklerini akademik destekleme çalışmalarına göre daha fazla kullanmalarının önemli nedenlerinden biri güdüleyici etkinlikleri akademik destekleme çalışmalarına göre kullanmada kendilerini daha yeterli hissetmeleri olabilir. Velilerin çocuklarının öğrenmelerini desteklemede kullandıkları akademik destekleme etkinliklerine göre onları güdülemek için kullandıkları stratejilerin günlük yaşantılarında da daha fazla karşılaştıkları durumlar olduğu söylenebilir. Araştırmanın katılımcılarının eğitim durumlarının büyük oranda ilkokul mezunu ya da ilkokul terk olması da güdüleme etkinliklerinin daha fazla belirtilmesinde etkili olmuş olabilir. Bæck (2010) da eğitim düzeyi düşük velilerin okul-aile işbirliği çalışmalarında özellikle çocuklarını akademik konularda desteklemede kendilerini daha yetersiz gördüklerini ifade etmektedir. Benzer şekilde Xu (2016) matematik ödevlerinde duyuşsal düzenlemeyi araştırdığı deneysel çalışmasında velilerin çocuklarının ödevlerini kontrol etmede eğitim düzeylerine göre gerçekleştirdikleri duyuşsal değerlendirmelerde bir farklılık olmadığı; ancak velilerin bilişsel değerlendirme yapabilmelerinin eğitim düzeylerine göre farklılaştığı sonucunu elde etmişlerdir. Bunun yanında Gubbins \& Otero(2018)kişilerin daha etkili ve daha fazla faydalı olabileceğini düşündüğü etkinliklere katılmada daha istekli olduğunu gösteren pek çok araştırma bulunduğunu ifade etmektedirler. Aile katılımı konusunda önemli çalışmaları olan HooverDempsey ve diğerleri (2015) bu durumu ailelerin veya velilerin sahip oldukları bilgi ve becerilerin çocuklarının eğitimine nasıl bir katkı sağlayabileceği konusundaki inançları olarak tanımladıkları özyeterlikleri ile ilişkilendirmektedirler. Bir başka önemli sebep de velilerin çocuklarının akademik öğrenmelerinden öğretmenlerinin sorumlu olduğunu düşünmeleri; kendilerinin rollerinin ise çocuklarını öğrenmeye karşı güdülemek olduğunu ve kendinden beklenilenin de bu olduğunu düşünmeleri olabilir.

Velilerin çocuklarının öğrenmelerini desteklemede diğer kişiler ve kurumlar ile gerçekleştirdikleri destekleme çalışmalarına bakıldığında ise bu çalışmaların daha çok veli toplantılarına katılmak ve çocuğun öğretmenleri ile iletişim kurmak yönünde olduğu; MEB ve okul tarafından düzenlenen bilgilendirici eğitim, konferans, seminer vb. etkinliklere katılan velilerin çok az olduğu görülmektedir. Alanyazında uluslararası aile katılımı çalışmalarında (Hornby \& Blackwell, 2018; Stanley, Vaterlaus, Tulane \& Beckert, 2017; Jezierski \& Wall, 2017) seminer, konferans gibi çocuklarına akademik destek sağlayabilme noktasında aile eğitimine yönelik çalışmalar vurgulansa da Türkiye'de yapılan aile katılımı çalışmalarında bu tür eğitici uygulamalardan bahseden çok az çalışma (Porsuk \& Kunt, 2012) bulunmaktadır. Türkiye'de velilerin bu etkinliklere katılımının az olmasının

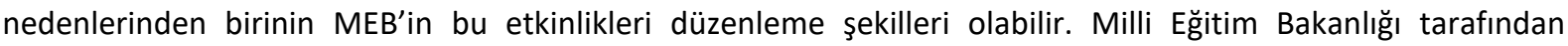
düzenlenen bu etkinlikler genelde velilerin tamamına yönelik uygulanamamakta ve farklı nedenlerle velilerin ancak bir kısmı bu etkinliklerden faydalanabilmektedir. Bu etkinliklerden faydalanabilen veliler genellikle çocukları okul davranışları ya da akademik başarıları açısından risk konumunda olanlar ya da çocukları özel eğitim gereksinimine intiyaç duyanlar olmaktadır. Bazı durumlarda ise bu etkinliklerden faydalanacak veliler 
okul idaresi ve öğretmenler tarafından evreni temsil edecek sayıda rastgele ya da okulun belirlediği belli ölçütler dikkate alınarak seçilmektedir. Örneğin; MEB, toplumsal gelişmeyi ve refahı güçlendirmek amacı ile yaygın eğitim faaliyetleri kapsamında yürüttüğü aile eğitimlerini öncelikli alan olarak ele alarak Aile Eğitimi Kurs Programları (0-18 yaş) düzenlenmiştir. Uygulamaya konulan program 0-3, 3-6, 7-11, 12-18 Yaş Aile Eğitimi Kurs Programları, 3-6 Yaş Aile Gelişim Kurs Programı, 3-6, 7-11 Yaş Baba Destek Eğitimi Kurs Programı ve 3-6 Yaş Okuryazar Olmayan Anne Destek Eğitimi Kurs Programı (Temel ADP)'ından oluşmaktadır (Hayat Boyu Öğrenme Genel Müdürlüğü, 2016). Gerçekleştirilen bu aile eğitimi çalışmaları MEB bünyesinde yaygın eğitim faaliyetleri kapsamında halk eğitim merkezlerinde gerçekleştirilmekte ve daha çok sosyoekonomik düzeyi düşük risk altındaki ailelerin çocuklarına hizmet sunmaktadır. İstanbul'daki resmi okullarda öğrenim gören öğrencilerin velilerine yönelik 2018-2019 öğretim yılından itibaren okul-veli iletişimini ve işbirliğini güçlendirmek amacıyla düzenlenen veli akademilerinden de tüm velilerin yararlanamaması durumu devam etmektedir (İstanbul Milli Eğitim Müdürlüğü, 2019). Veli akademilerinde anlatılacak olan konular okul idaresi tarafından bölgenin velilerinin ihtiyaçları da dikkate alınarak belirlenmekte ve bu veli akademilerine katılacak veliler okulun fiziki imkânları doğrultusunda her sınıftan belli sayıda olmaktadır. Velilerin bu etkinliklere hiç katılım göstermemelerinde okullarında bu tür etkinliklerin düzenlenmemesi de etkili olabilir. Akbaşlı ve Kavak (2008) okullarda okul-aile birliklerinin öğretimi ve eğitimi geliştirme konularında velileri aydınlatacak araç ve gereçlere sahip olmadıklarını, okulun programı ve ilgili yönetmelikler gibi bilgilendirici konularda velileri yeterince aydınlatıcı konferans vb. etkinlikler düzenlenmediğini belirtmektedirler. Argon ve Kıyıcı (2012) da ilköğretim kurumlarından ailelerin sürecine katılımlarına yönelik öğretmen görüşlerini belirledikleri çalışmalarında tüm velilere yönelik bilgilendirici konferans ve seminerlerin eksikliğinden bahsetmişler ve okul idaresi ile öğretmenlerin anne ve babanın görüşlerini alarak bu tip etkinliklerin tüm velilere yönelik aktif olarak gerçekleştirilmesini önermektedirler. Velilerin aile katılımına yönelik öğretmenle birlikte gerçekleştirdiklerini ifade ettikleri destekleme çalışmalarından en önemlisi ise veli toplantıları olmuştur. Velilerin büyük bir çoğunluğu veli toplantılarına düzenli katılmaya çalıştıklarını belirtmekle birlikte bir kısmı da veli toplantılarında konuşulan konunun genellikle okul için bağış toplamaya yönelik olduğunu düşündükleri ve bu durumdan rahatsız oldukları için katılmadıklarını söylemişlerdir. Aile katılımına yönelik özellikle Türkiye'de yapılan çalışmalarda velilerden para istenen maddi konuların hem okul idaresi ve öğretmenler hem de veliler için sorun teşkil eden bir durum olduğu görülmektedir. Bu bağlamda araştırmanın bulguları alanyazınla tutarlılık göstermektedir (Albez\& Ada, 2018; Nural, Kaya \& Kaya, 2013; Özgan \& Aygın, 2010; Porsuk \& Kunt, 2012).

Araştırmadan elde edilen sonuçlar doğrultusunda velilerin çocuklarının öğrenmelerini hem genel hem de derslere yönelik özel gerçekleştirdikleri akademik desteklemelerde yeterli düzeyde olmadığını göstermektedir. Okul-veli işbirliğinin velilerin çocuklarının eğitimlerini desteklemekte kendilerini eksik hissettikleri akademik etkinlikleri gerçekleştirmeye yönelik de yapılmasının ve okullar ile MEB tarafından ailelere yönelik aile eğitim programları düzenlenmesinin faydalı olacağı söylenebilir. Bununla birlikte eğitim programlarında ailenin çocuğunun okul öğrenmelerini nasıl destekleyebileceklerine yönelik eğitim etkinliklerine yer verilmesinin ailenin çocuklarının eğitimlerine katılımını artıracağı düşünülmektedir. Bu eğitim etkinlikleri velilerin çocukları evde ders çalışırken ya da ev ödevlerini yaparken onlara yardımcı olabilmelerine katkı sağlayacak öğrenme stratejileri, ders çalışma stratejileri, ergenliğin bu bağlamdaki etkileri, teknolojinin eğitimde kullanılması gibi akademik desteleme çalışmalarına yönelik olabilir. Alanyazında velinin yaşı ile aile katılımı arasındaki ilişkiyi inceleyen bir çalışmaya rastlanmamıştır. Bu araştırma sonucunda elde edilen ortaokul velilerinin yaşları ile çocuklarının öğrenmelerini destekleme düzeyleri arasındaki ilişkinin nedenlerinin daha ayrıntılı araştırılmasının gerekli olduğu düşünülmektedir. Gerçekleştirilmiş olan bu araştırmada eş zamanlı karma yöntem kullanılmıştır. Sıralı karma yöntem kullanılarak anket sonucunda elde edilen kritik bulgulara yönelik detaylı görüşmeler gerçekleştirilerek velilerin çocuklarının öğrenmelerini desteklemede en fazla sorun yaşadıkları konuların daha derinlemesine araştırılması sağlanabilir. Araştırmada nicel verilerin toplanmasında sadece anket kullanılması ve aynı okuldaki velilerin görüşlerinin alınması araştırmanın sınırlııkları olarak ifade edilebilir. Benzer bir çalışma farklı okullardaki velilerin görüşleri alınarak da gerçekleştirilmelidir. Öte yandan ölçek gibi daha ileri istatistiksel hesaplamaların yapılabileceği veri toplama araçlarının kullanılmasının velilerin gerçekleştirdikleri destekleme çalışmalarının onların demografik özellikleri gibi farklı değişkenler ile ilişkisinin incelenebilmesi açısından önemli olacağı düşünülmektedir. Ortaokul öğrencilerinin velileri ile yapılan bu çalışma farklı eğitim basamaklarına yönelik de gerçekleştirilerek eğitim sistemimizde ailelerin çocuklarının öğrenmesine ilişkin gerçekleştirdikleri ya da gerçekleştiremedikleri destekleme çalışmalarının daha bütünsel bir bakış açısıyla analiz edilmesine ve velilerin eksikliklerinin giderilmesine yönelik daha geniş yelpazede müdahaleler yapılmasına katkı sağlanabilir. 


\section{References}

Akbaşlı, S. \& Kavak, Y. (2008). Ortaöğretim okullarındaki okul aile birliklerinin görevlerini gerçekleştirme düzeyleri, Selçuk Üniversitesi Sosyal Bilimler Enstitüsü Dergisi, 19, 1-22.

Albez, C. \& Ada, Ş. (2018). Okul-aile ortaklığı: Güçlükler, Beklentiler, Gereksinimler, Öneriler. Anadolu Eğitim Liderliği ve Öğretim Dergisi, 5(2), 1-18.

Arens, A. K. \& Jude, N. (2017). Parental involvement and student achievement in two language domains: Indirect relations and generalizability across migration status. Learning and Individual Differences, 53, 145155.

Argon, T. \& Kıyıcı, C. (2012). İlköğretim kurumlarında ailelerin eğitim sürecine katılımlarına yönelik öğretmen görüşleri, Dicle Üniversitesi Ziya Gökalp Eğitim Fakültesi Dergisi, 19, 80-95.

Bæck, U. K. (2010). Parental involvement practices in formalized home-school cooperation. Scandinavian Journal of Educational Research, 54(6), 549-563.

Baki, A. \& Gökçek, T. (2012). Karma yöntem araştırmalarına genel bir bakış. Elektronik Sosyal Bilimler Dergisi, 11(42), 1-21.

Bayhan, P. \& Işıtan, S. (2010). Ergenlik döneminde ilişkiler: Akran ve romantik ilişkilere genel bakış. Aile ve Toplum, 5(20), 33-44.

Büyüköztürk, Ş., Kılıç-Çakmak, E., Akgün, Ö.E., Karadeniz, Ş., \& Demirel, F. (2017). Bilimsel araştırma yöntemleri $\left(23^{\text {th }}\right.$ edition). Ankara: Pegem Yayınları

Caputo, V. (2007). "She's from a 'Good Family': Performing childhood and motherhood in a Canadian private school setting." Childhood, 14(2): 173-192.

Celep, C. (2008). Sınıf yönetiminde kuram ve uygulama. Ankara: Pegem Yayıncılık.

Creswell, J. W. (2003). Research design: Qualitative, quantitative, and mixed methods approaches ( $2^{\text {nd }}$ ed.). Thousand Oaks, CA: Sage.

Creswell, J. W. (2013). Nitel araştırma yöntemleri: Beş yaklaşıma göre nitel araştırma ve araştırma deseni (Translated from the 3rd edition; M. Bütün \& S. B. Demir). Ankara: Siyasal Kitabevi.

Çayak, S. (2013). Öğretmen-veli işbirliği ile ilkokul öğrencilerinin sınıf içindeki istenmeyen davranışları arasındaki ilişki. Unpublished master's thesis, Trakya University, Edirne.

Çelenk, S. (2003). Okul başarısının ön koşulu: okul aile dayanışması, Ilköğretim-Online Dergisi, 2(2), 28-34.

Çelik, N. (2005). Okul-aile ilişkilerinde yaşanan sorunlar. Unpublished master's thesis, Marmara University, İstanbul.

Doğan, Y. (2007). Illköğretim çağındaki 10-14 yaş grubu öğrencilerinin gelişim özellikleri. Uludağ Üniversitesi Fen-Edebiyat Fakültesi Sosyal Bilimler Dergisi, 2 (13), 155-187.

Edwards, R. \& Val, G. (2011). Clients or consumers, commonplace or pioneers? Navigating the contemporary class politics of family, parenting skills and education. Ethics and Education, 6(2). 141-154.

Fantuzzo, J. W., Tighe, E., \& Childs, S. (2000). Family involvement questionnaire: A multivariate assessment of family participation in early childhood education. Journal of Educational Psychology, 92, 367-376.

Gonzalez- DeHass, A., Willems, P. P., \& Holbein, M. D. (2005). Examining the relationship between parental involvement and student motivation. Educational Psychology Review, 17, 99-123.

Goodall, J. (2018). Learning-centered parental engagement: Freirere imagined. Educational Review, 70(5), 603621.

Göktürk, S. \& Dinçkal, S. (2018). Effective parental involvement in education: experiences and perceptions of Turkish teachers from private schools. Teachers and Teaching, 24 (2), 183-201.

Gubbins, V. \& Otero, G. (2018). Determinants of parental involvement in primary school: evidence from Chile. Educational Review, 1-20.

Gündüz, G. F. (2018). Sosyal ağ üzerinden gerçekleştirilen veli koçluğunda velilerin etkileşimlerinin ve çocuklarının öğrenme düzeylerinin incelenmesi. Universal Journal of Educational Research, 6(3), 491-518. 
Hill, N. E., \& Tyson, D. F. (2009). Parental involvement in middle school: A Meta-analytic assessment of the strategies that promote achievement. Developmental Psychology, 45 (3), 740-763.

Hoover-Dempsey, K., Walker, J., Sandler, H., Whetsel, D., Green, C., Wilkins, A. \& Closson, K. (2005). "Why do parents become involved? Research findings and implications." The Elementary School Journal 106(2): 105130. Doi:10.1086/499194.

Hornby, G. \&Blackwell, I. (2018). Barriers to parental involvement in education: an update. Educational Review. 70(1), 109-119.

İstanbul Milli Eğitim Müdürlüğü (2019). İstanbul Milli Eğitim veli akademileri. Retrieved from http://veliakademisi.istmem.com/

Jeynes, W. H. (2007). The relationship between parental involvement and urban secondary school student academic achievement: A meta-analysis. Urban Education, 42 (82). 82-110.

Jezierski, S. \& Wall, G. (2017). Changing understandings and expectations of parental involvement in education. Gender and Education, 1-16. https://doi.org/10.1080/09540253.2017.1332340

Johnson, R. B., \& Onwuegbuzie, A. J. (2004). Mixed methods research: A research paradigm whose time has come. Educational Researcher, 33(7), 14-26.

Keith, T. Z., Keith, P. B., Kimberly, J. Q., Sperduto, J., Santillo, S., \& Killings, S. (1998). Longitudinal effects of parent involvement on high school grades: similarities and differences across gender and ethnic groups. Journal of School Psychology, 36(3), 335-363.

Keskin, G., \& Sezgin, B. (2009). Bir grup ergende akademik başarı durumuna etki eden etmenlerin belirlenmesi. Fırat Sağlık Hizmetleri Dergisi, 4(10), 1-18.

Kıncal, R. Y. (1999). Ailenin eğitimsel fonksiyonları. Erzurum: Atatürk Üniversitesi Yayınları.

Kotaman, H. (2008). Türk ana babalarının çocuklarının eğitim öğretimlerine katılım düzeyleri. Uludağ Üniversitesi Eğitim Fakültesi Dergisi, 21(1), 135-149.

Lareau, A. (2011). Unequal childhoods: Class, race, and family life. Berkeley, CA: University of California Press.

Lawson, M. A. (2003). School-family relations in context: parent and teacher perceptions of parent involvement. Urban Education, 38, 77-133.

Leech, N. L. \&.Onwuegbuzie, A. J. (2009). A typology of mixed methods research designs. Quality \& Quantity, 43(2), 265-275.

Lindberg, E.N. (2014). Eğitim fakültesi son sınıf öğrencilerinin aile katılımı ile ilgili görüşleri. Kuram ve Uygulamada Eğitim Bilimleri, 14(4), 1339-1361.

Lindberg, E. \& Oğuz, K. (2016). İlkokul ve ortaokullarda aile katılımı: Bir geçerlilik ve güvenirlilik çalışması. Journal of Human Sciences, 13(3), 4135-4151.

Milli Eğitim Bakanlığı [MEB]. (2012). Millî eğitim bakanlığı okul-aile birliği yönetmeliği. Retrieved from http://www.meb.gov.tr /mevzuat/liste. asp?ara=7 [10.05.2016]

Milli Eğitim Bakanlığı Talim ve Terbiye Kurulu Başkanlığı (2008). Öğrenci ve programı anlamaya yardımcı ilköğretim veli kılavuzu. Retrieved from http://www.fevziozbey.k12.tr/FileUpload/ks2827 /File/ veli_kilavuzu.pdf_[10.05.2016]

Morse, J. M. (2003). Principles of mixed methods and multi method research design. In A. Tashakkori \& C. Teddlie (Eds.), Handbook of mixed methods in social \& behavioral research (pp. 189- 208). Thousand Oaks, CA: Sage.

Nural, E., Kaya, C. D. \& Kay, Y. (2013). Okul aile birliklerinin işleyişi, sorunlarına ilişkin yöneticilerin, okul aile birliği üyelerinin görüşleri. Eğitim ve Öğretim Araştırmaları Dergisi, 2 (4), 58-69.

Oktay, A., Gürkan, T., Zembat, R. \& Unutkan, Ö. P. (2003). Ne yapıyorum? Neden yapıyorum? Nasıl yapmalıyım?. İstanbul: YA-PA Yayınları.

Özgan, H. \& Aydın, Z. (2010). Okul-aile işbirliğine ilişkin yönetici, öğretmen ve veli görüşleri. E-Journal of New World Sciences Academy, 5(3), 1169-1189.

Porsuk, A. \& Kunt, M. (2012). Denizli merkez ilköğretim okullarındaki okul aile ilişkilerinde karşılaşılan sorunlar üzerine yönetici görüşleri. Pamukkale Üniversitesi Eğitim Fakültesi Dergisi, 31, 203-218. 
Rogers, M. A., Theule, J., Ryan, B. A., Adams, G. R., \& Keating, L. (2009). Parental involvement and children's school achievement. Canadian Journal of School Psychology, 24 (1), 34-57.

Senler, B., \& Sungur, S. (2009). Parental influences on students' self-concept, task value beliefs, and achievement in science. The Spanish Journal of Psychology, 12 (1), 106-117.

Sheldon, S. B. (2007). Improving student attendance with school, family, and community partnerships. The Journal of Educational Research, 100(5), 267-275.

Sheldon, S.B. \& Epstein, J. L. (2007). Student survey of family and community involvement in the elementary and middle grades. Baltimore: Johns Hopkins University, Center on School, Family, and Community Partnerships.

Stanley, J. L., Vaterlaus, M., Tulane, S. \& Beckert, T. (2017). A place for technology in parent education: An exploratory study of parent perceptions. Marriage \& Family Review, 53 (8), 811-825.

Starr, L. (2011). A Dozen Activities to Promote Parent Involvement. Education World. Retrieved from https://www.educationworld.com/a_curr/curr200.shtml [18.01.2019]

Şad, N. (2012). Investigation of parental involvement tasks as predictors of primary students' Turkish, math and science \& technology achievement. Eğitim Araştırmaları, 49, 173-196.

Thomas, V., Muls, J., Backer, F. \& Lombaerts, K. (2019). Exploring self-regulated learning during middle school: views of parents and students on parents' educational support at home. Journal of Family Studies, 1-19.

Tulviste, T. \& Kikas, E. (2010). Qualities to be developed in children at home and at school: A comparison of the views of Estonian mothers, fathers and teachers. Journal of Applied Developmental Psychology, 31, 315321.

Türkiye Cumhuriyeti Hayat Boyu Öğrenme Genel Müdürlüğü. (2016). Aile Eğitimi Programı 0-18 yaş uygulamaları-2014/17 sayılı genelge. Retrieved from http://aileegitimi.meb.gov.tr/index.php

Ünal, A., Yıldırım, A. \& Çelik, M. (2010). İlköğretim okulu müdür ve öğretmenlerinin velilere ilişkin algılarının analizi. Selçuk Üniversitesi Sosyal Bilimler Enstitüsü Dergisi, 23, 261-272.

Walker, J. M. T., Wilkins, A. S., Dallaire, J. R., Sandler, H. M., \& Hoover-Dempsey, K. V.. 2005. "Parental Involvement: Model Revision through Scale Development." The Elementary School Journal 106 (2): 85-104. doi:10.1086/499193.

Wall, G. (2013). “Putting Family First': Shifting Discourses of Motherhood and Childhood in Representations of Mothers' Employment and Child Care. Women's Studies International Forum 40, 162-171.

Williams, K., Swift, J., Williams, H. \& Daal, V. (2017). Raising children's self-efficacy through parental involvement in homework. Educational Research, 59 (3), 316-334.

$\mathrm{Xu}$, J. (2016). Emotion regulation in mathematics homework: An emprical study. The Journal of Educational Research, 111 (1), 1-11.

Yıldırım, A. \& Şimşek, H. (2011). Sosyal bilimlerde nitel araştırma yöntemleri. Ankara: Seçkin Yayıncılık. 